This is an author produced version of a paper published in Biomass \& Bioenergy.

This paper has been peer-reviewed but may not include the final publisher proof-corrections or pagination.

Citation for the published paper:

Prade, Thomas; Svensson, Sven-Erik; Matsson, Jan Erik. (2012) Energy

balances for biogas and solid biofuel production from industrial hemp.

Biomass \& Bioenergy. Volume: 40, pp 36-52.

http://dx.doi.org/10.1016/j.biombioe.2012.01.045.

Access to the published version may require journal subscription.

Published with permission from: Elsevier.

Epsilon Open Archive http://epsilon.slu.se 


\section{Energy balances for biogas and solid biofuel production from}

\section{2 industrial hemp}

3

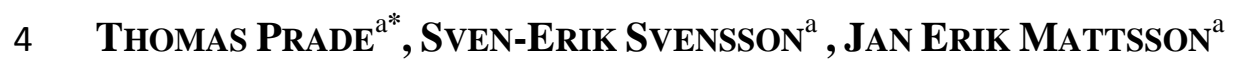

$5 \quad{ }^{a}$ Department of Agrosystems, Swedish University of Agricultural Sciences, Box 104,

6 SE-23053 Alnarp, Sweden

$7 \quad$ *Corresponding author: e-mail: thomas.prade@ slu.se; phone number:

$8 \quad+46404151$ 57; fax number: +4640462166

9

10 Co-authors e-mail: $\quad$ sven-erik.svensson@slu.se

11

jan.erik.mattsson@slu.se 
Abstract

If energy crops are to replace fossil fuels as source for heat, power or vehicle fuel, their whole production chain must have higher energy output than input. Industrial hemp has high biomass and energy yields. The study evaluated and compared net energy yields (NEY) and energy output-to-input ratios $\left(\mathrm{R}_{\mathrm{O} / \mathrm{I}}\right)$ for production of heat, power and vehicle fuel from industrial hemp. Four scenarios for hemp biomass were compared; (I) combined heat and power (CHP) from spring-harvested baled hemp, (II) heat from spring-harvested briquetted hemp, and (III) CHP and (IV) vehicle fuel from autumnharvested chopped and ensiled hemp processed to biogas in an anaerobic digestion process. The results were compared with those of other energy crops. Calculations were based on conditions in the agricultural area along the Swedish west and south coast. There was little difference in total energy input up to storage, but large differences in the individual steps involved. Further processing to final energy product differed greatly. Total energy ratio was best for combustion scenarios (I) and (II) ( $\mathrm{R}_{\mathrm{O} / \mathrm{I}}$ of 6.8 and 5.1, respectively). The biogas scenarios (III) and (IV) both had low $\mathrm{R}_{\mathrm{O} / \mathrm{I}}(2.6)$. They suffer from higher energy inputs and lower conversion efficiencies but give high quality products, i.e. electricity and vehicle fuel. The main competitors for hemp are maize and sugar beets for biogas production and the perennial crops willow, reed canary grass and miscanthus for solid biofuel production. Hemp is an above-average energy crop with a large potential for yield improvements.

34 Keywords: net energy yield, utilisation pathway, fibre hemp, energy crop, scenario, Cannabis sativa L. 
37 Biomass from agricultural crops has been suggested as an alternative source of energy that has the potential to partly replace fossil fuels for heat, power and vehicle fuel production [1-3]. The replacement of fossil fuels is desirable for the mitigation of $\mathrm{CO}_{2}$ emissions among other aims. However, for mitigation of $\mathrm{CO}_{2}$ emissions, replacement of fossil fuels with biofuels based on the energy content is crucial. The fossil fuels used for producing the biofuels must also be accounted for. Recent studies have challenged the ability of biofuels to reduce $\mathrm{CO}_{2}$ emissions, e.g. bioethanol from sugarcane or maize [4] or biodiesel from rapeseed oil [5]. Some biofuels have been reported to increase overall $\mathrm{CO}_{2}$ emissions, when the complete well-to-wheel production pathway is considered (e.g. [6]). Important parameters influencing the environmental sustainability of biofuels include inflicted land-use change, utilisation of by-products or origin of auxiliary energy [7]. Major concerns relate to the resource efficiency of agricultural biomass production (e.g. [6]).

Energy crops are often compared in terms of resource efficiency, e.g. arable land type, environmental impact, energy and economic efficiency of the gaseous, liquid or solid energy carriers produced [8]. For each well-to-wheel production pathway an energy balance can be calculated that accounts for the energy outputs minus the direct and indirect energy inputs in cultivation, harvest, transport and conversion [9]. Energy balances have been drawn up for most of the first generation energy crops, for example maize (e.g. [10]) and wheat (e.g. [11]) for bioethanol production and rape seed oil for biodiesel production (e.g. [12]). However, energy balances are lacking for many other crops that are in the stage of commercial introduction as energy crops, e.g. industrial hemp, or for new applications of common crops, e.g. biogas from residual agricultural biomass. 
Hemp (Cannabis sativa L.) can be used to produce different energy products such as heat (from briquettes or pellets [13, 14]), electricity (from baled biomass [15]) or vehicle fuel (e.g. biogas from anaerobic digestion [16]) or bioethanol from fermentation [17]). Hemp has potential energy yields that are as high as or higher than those of many other energy crops common in northern Europe, e.g. maize or sugar beet for biogas production and reed canary grass as solid biofuel [18]. As an annual herbaceous crop, hemp fits into existing crop rotations. Hemp requires little pesticide and has been shown to have the potential to decrease pesticide use even for the succeeding crop [19], as it is a very good weed competitor [20]. These characteristics of hemp potentially improve the energy balance, as production of pesticides requires large amounts of energy [21]. Energy conversion of hemp biomass to biogas or bioethanol has been shown to have promising energy yields $[16,17]$. Energy utilisation of hemp biomass processed to solid biofuels in the form of briquettes has been established commercially, and is competitive in a niche market [22].

When comparing energy crops with each other based on their environmental performance (e.g. emissions from production and use of fertiliser, fossil fuel, etc.), it is important to also know the emissions avoided by replacing other sources of energy, i.e. fossil fuels. However, this requires an energy balance, including the energy inputs and outputs of the conversion investigated. Earlier studies regarding the use of hemp for energy purposes have concentrated on calculating the emissions from sole biomass production [23], from electricity production from hemp-derived biogas [24], from hemp diesel production [25] and from hemp pulp production [26]. To our knowledge, no other energy use of hemp biomass (e.g. for biogas, bioethanol or solid biofuel production) has been investigated in reference to its energy balance. 
87 The aim of the present study was to evaluate and compare the energy balances of four

88 scenarios for the production of hemp biomass and further fuel processing. These

89 scenarios were: (I) combined heat and power (CHP) from spring-harvested baled hemp,

90 (II) heat from spring-harvested briquetted hemp, and (III) CHP and (IV) vehicle fuel

91 from autumn-harvested chopped and ensiled hemp processed to biogas in an anaerobic

92 digestion process. An additional aim was to compare hemp with other biomass sources

93 used for the final energy products investigated. 


\section{Methodology}

\subsection{Description of base scenarios}

The different utilisation pathways for hemp biomass can be grouped in terms of two different biomass harvest times: Hemp harvested as green plants in autumn if intended for biogas, or as dry plants in spring if intended for solid biofuel production [18]. To compare these pathways, four different energy conversion base scenarios were investigated (Fig. 1).

Scenario I describes combined heat and power (CHP) production from combustion of spring-harvested baled hemp. In this scenario, hemp would act as a complement to straw fuel in a large-scale CHP plant, e.g. as is common in Denmark [27]. In CHP production, the combustion heat is used for production of both electricity (power) and heat, e.g. for residential and commercial district heating.

Scenario II describes the production of heat from combustion of spring-harvested, chopped and briquetted hemp. This scenario illustrates the utilisation currently available in parts of Sweden, i.e. combustion in small-scale boilers for heating of private homes $[28]$.

Scenario III describes the production of CHP from biogas derived by anaerobic digestion of autumn-harvested chopped and ensiled hemp. This scenario outlines how biogas (mostly from maize digestion) is commonly used in Germany [29].

Scenario IV describes the production of vehicle fuel from biogas derived by anaerobic digestion of autumn-harvested chopped and ensiled hemp. This scenario depicts the situation of how biogas (of other origin than hemp) is increasingly being used in Sweden, Germany and other European countries as vehicle fuel [30].

\subsection{Scenario assumptions}




\subsubsection{Cultivation area}

120 Hemp biomass was assumed to be produced in the agricultural area called Götalands södra slättbygder, Gss, extending over the Swedish west and south coast, up to $35 \mathrm{~km}$ inland $\left(55^{\circ} 20^{\prime}-57^{\circ} 06^{\prime} \mathrm{N}, 12^{\circ} 14^{\prime}-14^{\circ} 21^{\prime} \mathrm{E}\right)$ [31]. On average, this area produces high

123 yields per hectare of conventional crops. Gss comprises approx 330.000 ha arable land $124[31,32]$ and is also the area where hemp could be grown with relatively high biomass and energy yields per hectare [18]. A typical short crop rotation in this area is sugar beet followed by spring barley and winter wheat. This rotation was assumed to be extended with one year of hemp cultivation following either sugar beet or winter wheat. It was further assumed that the farm cultivates 150 ha arable land conventionally, with an average field size of 4 ha, reflecting the actual average farming situation in the agricultural area investigated $[33,34]$.

\subsubsection{Soil treatment}

Soil treatment was assumed to comprise stubble treatment, ploughing and seedbed preparation. Sowing was assumed to be carried out in combination with fertilisation, with subsequent light soil compaction by a roller. Pesticide treatment was assumed to be unnecessary [19]. These field operations for establishing the hemp crop were identical for all scenarios tested in the present study.

\subsubsection{Scenario I}

140 Solid biofuel production in scenarios I and II requires harvest in spring, when moisture content (MC) in the biomass is below 30\% [18], which is required for safe, low-loss storage [35]. In scenario I, hemp was assumed to be cut and laid in swaths, then pressed into large square bales $(2.4 \mathrm{~m} \times 1.2 \mathrm{~m} \times 1.3 \mathrm{~m})$. The bales were transported $4 \mathrm{~km}$ on 
average to the farm (see section 2.4). For intermediate storage the bales were wrapped together in a plastic film tube, which is an economic storage option that does not require as much investment as permanent storage buildings. The bales were then transported on demand to a CHP plant, where they were combusted. A CHP plant with an annual production of $780 \mathrm{TJ}_{\mathrm{el}}\left(217 \mathrm{GWh}_{\mathrm{el}}\right)$ and $1430 \mathrm{TJ}_{\text {heat }}\left(397 \mathrm{GWh}_{\text {heat }}\right)$ was assumed, which is similar to the dimensions of existing large-scale straw-firing CHP plants, e.g. [27, 36]. Baled wheat straw is typically the predominant fuel in such plants and was assumed to account for $95 \%$ of the energy produced in the present scenario. The remaining $5 \%$ were assumed to be accounted for by baled hemp biomass. The bales were fed into the boiler by means of a conveyor belt. The CHP plant was assumed to be equipped with a flue gas condensing unit for heat recovery [36]. Table A.1 lists the major process parameters. The complete amount of ash was assumed to be transported back to the field and used for fertilising the soil for the next crop. A standard lime spreader was used for spreading. It was further assumed that the amount of ash returned per hectare corresponded to the amount of ash produced from the biomass removed from one hectare [37].

\subsubsection{Scenario II}

For briquette production, hemp is also spring-harvested. Here it was assumed that hemp was chopped (20 mm length) with a maize forage harvester in the field and transported in bulk to the farm, where it was stored dry by compressing it into a silage tube for intermediate storage. Further processing included on-site pressing into briquettes, packaging and transport to local sales places and customers. It was further assumed that $50 \%$ of the briquettes were sold as $12 \mathrm{~kg}$ bags at petrol stations [38]. Individual transport of the briquettes to the place of combustion was not accounted for, as it was 
assumed that the bags were picked up 'on route'. The remaining 50\% were assumed to be delivered to the place of utilisation in $450 \mathrm{~kg}$ bulk bags [38]. The average transportation distance for both bag sizes was calculated (see section 2.4) to be $30 \mathrm{~km}$ on average. In both cases, briquettes were assumed to be burned in small-scale domestic boilers ( $80 \%$ thermal efficiency) for heating purposes.

\subsubsection{Scenario III}

For the production of biogas, hemp is harvested in autumn when the biomass DM yield is highest [18]. In this scenario, it was assumed that the crop was harvested by chopping (20 mm length) with a maize forage harvester in the field and transported to the biogas plant, where it was ensiled in a silage tube for intermediate storage. The silage was then fed on demand to the biogas plant. In the biogas reactor the hemp was converted to biogas and a nutrient-rich digestate. The hemp biomass was assumed to be co-digested with maize in a medium-sized biogas plant with an annual production of $90 \mathrm{TJ}$ raw biogas. This capacity corresponds to typical centralised or industrial biogas plants commonly digesting biomass from varying sources [39]. In the present scenario, hemp accounted for $20 \%$ of the energy produced, with maize accounting for the remainder. With such a low proportion of hemp, process parameters are likely to resemble those for a process run exclusively on maize. Therefore, this setup was assumed to be realistic for the implementation of a new energy crop as substrate in anaerobic digestion.

The raw biogas was assumed to be combusted in an on-site CHP plant (Fig. 2, top) with total annual production of $30 \mathrm{TJ}$ electricity and $40 \mathrm{TJ}$ heat. Table A.2 lists the major process parameters used in the present study. Pumping and mixing of the digestion process were assumed to use electricity, while heating of the biogas plant was assumed to use heat from the CHP process, using raw biogas as fuel [40]. 
The digestate was assumed to be stored at the biogas plant until utilisation as

195

196

197 biofertiliser. Fertilisation with digestate was assumed to partly replace mineral fertiliser according to its nutrient content in the production of hemp biomass in the following growing season. Only plant-available ammonium nitrogen $\left(\mathrm{NH}_{4}-\mathrm{N}\right)$ content in the digestate was assumed to replace mineral nitrogen fertiliser. The amount of $\mathrm{NH}_{4}-\mathrm{N}$ in the digestate was calculated from biomass elemental analysis (unpublished results) assuming the degree of mineralisation of the biomass in the digestion process as the production rates of methane and carbon dioxide suggest. Losses of $\mathrm{NH}_{4}-\mathrm{N}$ in the handling and spreading of digestate were set at 5\% [41]. Additional organically bound $\mathrm{N}$ was not accounted for. All phosphorus $(\mathrm{P})$ and potassium $(\mathrm{K})$ removed from the fields with the harvested biomass was assumed to be returned through use of the digestate as biofertiliser and to directly replace mineral $\mathrm{P}$ and $\mathrm{K}$ fertiliser, respectively. Transport of digestate from biogas plant to field was assumed to be achieved by tank truck with no prior dewatering, as transport distances are relatively short [40].

\subsubsection{Scenario IV}

In scenario IV, hemp biomass was assumed to be used and treated as described in scenario III until the production of raw biogas. However, instead of combusting the biogas, it was refined to vehicle fuel (Fig. 2, centre). This upgrading was assumed to be carried out in a subsequent water scrubber unit, which is a common choice of technology in Sweden [42]. The upgrading unit increases the methane content to $97 \%$ in the biogas, which is then pressurised to 200 bar. The upgrading unit was assumed to have an annual nominal production of $90 \mathrm{TJ}$ of biogas vehicle fuel. The biogas vehicle fuel was assumed to be distributed non-publicly directly at the biogas plant, e.g. for vehicles in public transport. 
In contrast to scenario III, heating of the biogas plant was assumed to use heat from a gas boiler, using raw biogas as fuel [40]. Note that scenarios III and IV refer to the same amount of biomass utilised.

\subsection{Calculation of energy balances}

224 For all scenarios, the net energy yield (NEY) was calculated by subtracting the sum of 225 direct and indirect energy inputs from the energy output. The energy output-to-input ratio $\left(\mathrm{R}_{\mathrm{O} / \mathrm{I}}\right)$ was calculated by dividing the gross energy output by the accumulated energy input of each scenario. These calculations were carried out for two different system boundaries: (a) From cultivation until intermediate storage of the hemp biomass (Fig. 1, top) and (b) from cultivation until distribution of the final energy product (Fig. 1, bottom).

\subsubsection{Energy input}

Table 1 lists the energy equivalents for production means that were assumed for energy input calculations. Energy input was calculated as the sum of direct and indirect energy inputs [43-45]. Direct inputs accounting for fuel consumption from field, transport and storage operations were assumed to be based on the use of fossil diesel, reflecting the current situation. Values for diesel consumption were taken from reference data [46]. Other direct energy inputs were heat energy (e.g. for heating the biogas digester) and electricity (e.g. for operation of the briquette press, digester pumping and mixing).

240 Human labour and production and utilisation of non-storage buildings and demolition/recycling of machinery and building materials were not accounted for, as these were regarded as minor. Solar radiation was not accounted for as it is free. 
243 Indirect energy inputs accounted for the energy use in production of seeds, fertiliser,

244 machinery, diesel fuel and electricity, as well as in maintenance (lubricants, spare parts)

245 of the machinery used [47]. All fertiliser inputs other than digestate and ash were based

246 on use of mineral fertilisers, according to common practice in conventional agricultural

247 production. The energy contained in machinery was calculated based on the energy used

248 for production of the raw material, the production process and maintenance and spare

249 parts [48]. Machinery for soil treatment and briquette pressing is usually owned by the

250 farmer and was assumed to be so in this study. Machinery capacity data ([46]; hemp

251 harvest: unpublished results) was used to calculate the annual machinery-specific

252 operating hours based on the assumed crop rotation (Table A.3). Machinery and

253 equipment for harvest and transport were assumed to be owned by a contractor,

254 resulting in high numbers of annual machinery operating hours (Table A.3).

255 The indirect energy for the straw-fired CHP plant was accounted for as $4 \%$ of the power

256 produced [49]. Indirect energy for the building materials used for the anaerobic digester

257 system was assumed on the basis of a simplified construction including a steel tank

258 digester and steel-reinforced concrete tanks with gastight plastic roofing for storage of

259 the digested residues. Indirect energy for the upgrading plant and for the transport,

260 assembly and demolition of the biogas plant was assumed to be minor and was not

261 accounted for.

262

\subsubsection{Hemp biomass yields and energy output}

264 Assumptions of realistic hemp biomass dry matter (DM) yields, MC and corresponding heating values at harvest dates suitable for biogas and for solid biofuel production have been reported earlier [18] and were used unaltered in this study (Table 2). Harvest time- 
related biomass energy content was calculated from the biomass DM yields and the corresponding higher heating value (HHV) [18].

Table 2 lists the assumed values of parameters used in calculation of the energy balance. $\mathrm{N}$ fertilisation was assumed to follow recommendations for hemp cultivation $[14,19]$. $\mathrm{P}$ and $\mathrm{K}$ fertilisation was based on actual nutrient removal rates at the corresponding

272 harvest time as derived from elemental analysis of biomass samples (unpublished 273 results).

274 In modelling biogas production from hemp, harvest in September-October was assumed to result in a biomass DM yield of $10.2 \mathrm{Mg} \mathrm{ha}^{-1}$ [18] and a volatile solids (VS) content of $95 \%$ of the DM content [16]. The gross energy output as biogas was then calculated using a specific methane yield of 0.22 normal cubic metre $\left(\mathrm{Nm}^{3}\right.$; standardised at $273 \mathrm{~K}$ and $100 \mathrm{kPa}$ ) $\mathrm{kg}^{-1} \mathrm{VS}$, which was assumed to be a realistic value in commercial production $[16,24]$ (Table 2).

The energy output for the use of hemp biomass as solid biofuel was calculated from the hemp DM yield and the corresponding heating value: For combustion of bales in a CHP plant equipped with a heat recovery unit, the HHV was used. For combustion of briquettes in a simple boiler or wood stove, the lower heating value (LHV) was used. The biomass was assumed to be harvested in spring, corresponding to a $\mathrm{MC}$ of $15 \%$ and a DM yield of $5.8 \mathrm{Mg} \mathrm{ha}^{-1}$ [18]. The low MC is advantageous for combustion, but is also a requirement $(\mathrm{MC} \leq 15 \%)$ for briquetting of the biomass [22].

\subsection{Transport distances}

Transport distances of biomass from field to storage and of digestate from biogas plant to field were calculated according to Eq. 1 [50]:

291 $\mathrm{d}=2 / 3 * \tau * \mathrm{r}$ Eq. 1 
where $\mathrm{d}(\mathrm{km})$ is the average transport distance, $\tau$ the tortuosity factor and $\mathrm{r}(\mathrm{km})$ the radius of the area (for simplicity assumed to be circular with the farm or processing plant in the centre) in which the transport takes place. The tortuosity factor describes the ratio of actual distance travelled to line of sight distance [50]. The parameter $\tau$ can range from a regular rectangular road grid $(\tau=1.27)$ to complex or hilly terrain constrained by e.g. lakes and swamps $(\tau=3.00)$ [50]. In this study a median value for $\tau$ of 2.14 was assumed.

Transport distances for briquettes to petrol stations and bulk customers were calculated as the radius for coverage of $25 \%$ of the study area, using Eq. 1 . The coverage area was assumed to provide sufficient customers for the scope of briquette production studied.

\subsection{Distribution of energy products}

The final energy products have to be transported to the final consumers. In the case of heat this is accomplished in a local district heating grid connected to the heat-producing plant. Heat losses were assumed to be $8.2 \%$ [51]. Heat from briquette combustion was assumed to occur at the place of heat utilisation, with distribution losses being negligible. Electricity was assumed to be distributed via the electrical grid with losses being $7.6 \%$ [51]. Biogas vehicle fuel was assumed to be distributed as $97 \%$ methane via a gas filling station directly at the biogas plant, where all biogas vehicle fuel was used for public transportation. As a subscenario to scenario III (section 2.6), biogas was assumed to be further upgraded to natural gas quality (NGQ) and transported to public petrol stations by a natural gas grid. The biogas pipeline to connect the biogas plant to the natural gas grid was assumed to be $25 \mathrm{~km}$ long, reflecting the geography of the study area and location of the natural gas grid (not shown). 
318 A sensitivity analysis was carried out on subscenarios in order to investigate the effect of a number of parameters on the energy input and the NEY of hemp used for energy in all base scenarios.

321 Diesel consumption for cultivation and transportation, biomass DM yield and transport

322 distances had been identified earlier as sensitive parameters in similar scenarios [52].

323 Therefore, these parameters were varied in subscenarios to all four base scenarios and their effect on the NEY recorded.

In scenario IV, biogas was assumed to be used to heat the anaerobic digestion process. It may be of economic interest to use all the biogas for upgrading to vehicle fuel, e.g. in order to maximise high value output. Therefore, a subscenario with an alternative external heat source, e.g. a wood chip boiler or residual heat available nearby, was tested (Fig. 2, centre and bottom).

Furthermore, in scenario IV the biogas vehicle fuel, which is similar to compressed natural gas $(\mathrm{CNG})$, was assumed to be distributed at a gas filling station directly at the biogas plant. In a subscenario, the biogas was instead assumed to be distributed to public petrol stations via a natural gas grid (Fig. 2, centre and bottom). In such cases, biogas vehicle fuel is mixed with natural gas, requiring prior adjustment of the Wobbe index of the biogas (97\% methane content) to NGQ in north-western Europe. This is usually done by adding liquid petroleum gas (LPG) to $8 \%$ content by volume [53]. Note that adjustment of the Wobbe index is only required where the heating value of the natural gas in the grid exceeds the heating value of the injected biomethane, e.g. in Sweden and Denmark [54]. Furthermore, compression of the biogas to only 5 bar instead of 200 bar is sufficient for distribution in the local gas grid. 


\subsection{Energy balance of hemp biomass production up to intermediate storage}

344 The energy input in cultivation, harvest, transport and intermediate storage was found to

345 be 11.7 and $13.0 \mathrm{GJ} \mathrm{ha}^{-1}$ for baled and briquetted solid biofuel production from spring-

346 harvested hemp, respectively, and 12.2 $\mathrm{GJ} \mathrm{ha}^{-1}$ for autumn-harvested, ensiled hemp

347 biomass for biogas production (Fig. 3, top). Although the scenarios showed similar energy inputs, there were large differences in where these inputs were required.

Nutrient recycling via digestate (see section 3.4) credited cultivation of autumnharvested hemp with the use of a reduced amount of mineral fertiliser, resulting in 3.13.6 GJ ha ${ }^{-1}$ less energy input than in cultivation of spring-harvested hemp (Fig. 3, top). However, this was counterbalanced by higher requirements for storage and transport in autumn-harvested hemp (Fig. 3, top). Detailed results on direct and indirect energy input in cultivation, transport and intermediate storage are provided in Table A.4.

\subsection{Energy balance of hemp biomass up to final energy product}

The four base scenarios differed substantially in their relative amount of energy input in the form of diesel, electricity, fertiliser, machinery and other equipment, production materials and heat requirements (Fig. 3, bottom).

Subsequent processing of the stored biomass requires energy inputs for conversion and additional transport. Conversion energy requirements differed substantially between the scenarios: inputs were low for solid biofuel combustion in the form of briquetted biomass (0.8 GJ ha $\left.{ }^{-1}\right)$ and for CHP production from bales (1.5 GJ ha' ${ }^{-1}$ (Fig. 3, bottom).

364 CHP production from biogas was more energy-intense $\left(2.8 \mathrm{GJ} \mathrm{ha}^{-1}\right)$. The most energydemanding conversion was the production of vehicle fuel, where the upgrading of the biogas to $97 \%$ methane content represented $45 \%$ of the total energy input. This is 
367 reflected in the high amount of electricity required for scrubbing and compression of the 368 biogas (Fig. 3, bottom).

369 The NEY was highest for CHP production from bales and heat from briquettes (Fig. 4),

370 with high overall conversion efficiencies (86 and $80 \%$, respectively) and high output-to-

371 input ratios ( $\mathrm{R}_{\mathrm{O} / \mathrm{I}}$ of 6.8 and 5.1, respectively). The NEY of biogas CHP and vehicle fuel

372 production was substantially lower. Conversion efficiency was $38 \%$ for upgraded

373 biogas (vehicle fuel) and $21 \%$ for biogas CHP. Both scenarios had a $\mathrm{R}_{\mathrm{O} / \mathrm{I}}=2.6$.

374 For each tonne DM increase in biomass yield, NEY increased by 15.7, 13.1, 3.9 and 5.8

$375 \mathrm{GJ} \mathrm{ha}^{-1}$ for scenarios I to IV, respectively (Fig. 5, top). Fig. 5. (bottom) shows the

376 influence of hemp biomass $\mathrm{DM}$ yield on $\mathrm{R}_{\mathrm{O} / \mathrm{I}}$ for each scenario. The two solid biofuel

377 scenarios were strongly yield-dependent, while the two biogas scenarios were far less

378 sensitive to changes in biomass DM yield.

379 Consumption of indirect energy excluding fertiliser-related indirect energy, i.e. energy

380 embodied in machinery and buildings and energy consumed in the production and

381 distribution of the energy carrier used, such as diesel, accounted for $26,35,39$ and $45 \%$

382 of the total energy input in scenarios I to IV, respectively. Fossil energy sources

383 accounted for $95 \%$ of the total energy input for scenarios I to III and $86 \%$ for scenario

384 IV.

385

386

\subsection{Variations in subscenarios}

387 Of the parameters tested, a $\pm 30 \%$ change in biomass yield had a substantial effect on

388 NEY. This effect was largest for scenario III $( \pm 45 \%)$, followed by scenario IV $( \pm 38 \%)$ and scenarios I and II ( \pm 34 and $\pm 35 \%$, respectively) (Fig. 6). Changes in diesel consumption $( \pm 30 \%)$ and transport distance $(-50 \% ;+100 \%)$ influenced NEY by less 
than $\pm 2 \%$ for solid biofuel production, by less than $\pm 5 \%$ for vehicle fuel production

392

393

394

395

396

397

398

399

400

401

402

403

404

405

406

407

408

409

410

411

412

413

414

415 from biogas and by less than $\pm 8 \%$ for CHP production from biogas (Fig. 6).

The choice of heat source (internal biogas or external heating) in scenario IV had only a marginal effect on NEY, which varied less by than $3 \%$ (Fig. 7). It was possible to increase NEY by approx $10 \%$ by compressing the biogas to 5 bar instead of 200 bar, and upgrading it to NGQ fuel for the scenarios with internal and external heat source (Fig. 7).

\subsection{Nutrient recycling}

The large difference in energy input in biomass cultivation between autumn- and springharvested hemp is mainly due to replacement of mineral fertiliser by nutrient-rich digestate from the anaerobic digestion of autumn-harvested hemp. Based on the nutrient content of hemp and maize, 55, 92 and $100 \%$ of mineral N, P and K, respectively, could be replaced in the cultivation of autumn-harvested hemp (scenarios III and IV). This represents an energy saving of $4.6 \mathrm{GJ} \mathrm{ha}^{-1}$, which corresponds to a reduction of $27 \%$ in the energy required for the cultivation and harvest of the biomass. The energy required for transport, storage and spreading of the digestate amounted to $1.6 \mathrm{GJ} \mathrm{ha}^{-1}$.

Utilisation of ash from combustion of hemp (together with straw in scenario I) as a fertiliser had a much more limited impact on the energy balance than digestate. Based on the nutrient content of hemp and straw, 39 and $100 \%$ of mineral P and K fertilisers, respectively, could be replaced in the cultivation of spring-harvested hemp. All $\mathrm{N}$ is lost in the combustion process. The replacement of mineral fertiliser by utilising the nutrients in the ash corresponded to a saving of $0.07 \mathrm{GJ} \mathrm{ha}^{-1}$. However, the energy required for transport and spreading of the ash amounted to $0.05 \mathrm{GJ} \mathrm{ha}^{-1}$. Fertiliser energy input amounted to approx. $7 \mathrm{GJ} \mathrm{ha}^{-1}$ for scenarios I and II and $3 \mathrm{GJ} \mathrm{ha}^{-1}$ for 
416 scenarios III and IV. This corresponded to 48, 43, 20 and $11 \%$ of the total energy input 417 in scenarios I to IV, respectively. 
$418 \quad$ References for Fig. 8.

419

420 R1

$421 \quad$ R2

[8]

422 R3

[45]

$423 \quad$ R4

[55]

424 R5 [57]

425 R6 [58]

426 R7 [40]

427 R8 [59]

428 R9 [24]

429

430 


\section{Discussion}

432

433

434

435

436

437

438

439

440

441

442

443

444

445

446

447

448

449

450

451

452

453

454

455

\subsection{Comparison with other biomass sources}

A comparison of the net energy yield per hectare of hemp with that of other biomass sources based on published data is shown in Fig. 8. The biomass DM yield per hectare of hemp in the base scenario is rather conservative. Furthermore, hemp is a relatively new energy crop with great potential for yield improvements and yields $31 \%$ above the base scenario (3-year average) for both autumn and spring harvest have been reported on good soils [18]. Therefore, in addition to the base scenario, the subscenario with biomass DM yield increased by $30 \%$ is shown (Fig. 8).

As harvested biomass in intermediate storage, hemp had similar NEY to other whole crop silages, e.g. from maize and wheat and similar to sugar beet according to a comparison based on the energy content of the harvested biomass (Fig. 8, top). Sugar beet including tops had 24\% higher NEY than hemp in the base scenario and a similar NEY to hemp with hemp biomass DM yields increased by $30 \%$. Furthermore, since sugar beet requires about $70 \%$ higher energy input in biomass production, its energy $\mathrm{R}_{\mathrm{O} / \mathrm{I}}$ is about $40 \%$ lower than that of hemp in the base scenario [8]. The NEY of ley crops seems rather low in comparison, but was based on 5-year average yields [8]. These are relatively low compared with those in highly intensive cultivation due to a high proportion of lower-yielding organic cultivation and to partly less intensive cultivation techniques [31].

For solid biofuel production, hemp biomass NEY was substantially lower than that of perennial energy crops such as miscanthus or willow, and even that of whole-crop rye (Fig. 8, top). Hemp has a similar biomass NEY to reed canary grass (Fig. 8, top), which is reflected in similar heat and CHP production of these two crops (Fig. 8, centre). Production of electricity only, i.e. not CHP, from hemp is relatively inefficient with $\mathrm{R}_{\mathrm{O} / \mathrm{I}}$ 
only 2.6 (Fig. 8, centre). Even if the NEY of willow were recalculated for a comparable electric efficiency [56] and a comparable biomass DM yield (not shown) [57] as in the present study, it would still be about twice that of hemp (not shown).

Production of raw biogas from hemp has similar NEY to that of ley crops, while maize has about twice the NEY of hemp (Fig. 8, bottom), mostly due to higher specific methane yield [59]. These results are reflected again in electricity and vehicle fuel production from biogas (upgraded) for these crops. Miscanthus and willow grown in Denmark and southern Sweden have a higher biomass yield, while their methane potential is similar to that of hemp (not shown), resulting in 43 and $28 \%$ higher NEY, respectively (Fig. 8, bottom). With a 30\% increase in biomass yield, hemp has a similar NEY to miscanthus and willow, while maize still has 50\% higher NEY.

Generally for all biomass sources, electricity production from biogas has a relatively low NEY due to the double conversion biomass to biogas and biogas to electricity. The NEY could be improved if the heat from power generation were used for heating purposes, i.e. in residential or commercial heating by employing combined heat and power (CHP) production. Hemp in the present study had similar NEY to triticale and 18, 29 and 46\% lower NEY than rye, barley and maize, respectively (Fig. 8, bottom). Another study has found a lower NEY for hemp, due to lower energy output [24]. For the production of upgraded biogas, sugar beet has a substantially higher NEY than hemp, mainly due to much higher methane potential. However, since energy inputs for utilisation of sugar beet are substantially higher than those of hemp, the $\mathrm{R}_{\mathrm{O} / \mathrm{I}}$ is similar to that of hemp.

Comparison of the data from the present study to that from other studies also shows that the production and conversion models employed for calculating the energy balance can differ substantially, the two most variable parameters being the biomass DM yield (e.g. 
due to fertilisation, climate and soil conditions) and the conversion efficiency (e.g. due to methane potential, thermal/electrical efficiencies of the technology of choice). For example, it is often unclear whether dry matter yields are based on experimental data or data on commercial production, i.e. accounting for field and harvest losses. A comparison of this kind therefore needs to bear in mind the variability of assumptions upon which the investigated scenarios are based.

\subsection{Energy-efficient utilisation of hemp biomass}

Hemp biomass can be utilised in many different ways for energy purposes. However, the four scenarios investigated in the present study exhibited large differences in conversion efficiency, energy output and NEY. When directly comparing the outcome of the scenarios, it should be noted that energy products of different energy quality were compared. Higher quality energy products often require higher energy inputs and have more conversion steps where losses occur, as well as lower conversion efficiencies. For example, biogas vehicle fuel has a high energy density and can be stored with minimal losses. In contrast, heat can be generated with high conversion efficiency, but utilisation is restricted to short-term use in stationary installations (e.g. a district heating grid). However, the direct comparison of energy products derived from the same biomass source can show the best alternative utilisation pathway in a specific situation. Just as for many other energy crops, utilisation of hemp has not yet been implemented on a large scale. This study shows examples of how relatively small cultivation areas of hemp can be utilised for production of renewable energy products, e.g. briquette production. However, large-scale hemp biomass utilisation can be implemented with the hemp acting as co-substrate for biogas production or co-fired solid biofuel. 
505 The most efficient energy conversion is from hemp biomass to heat and power by

506 combustion, e.g. of bales (scenario I). This is in agreement with a review of findings

507 that puts the highest energy yields at $170-230 \mathrm{GJ} \mathrm{ha}^{-1}[60]$. A $30 \%$ increase in the

508 biomass DM yield of hemp would result in hemp being just above the upper limit, i.e. in

509 a very competitive spot, together with most perennial crops.

510 Since heat has a low energy quality, this option is only viable where heat can be utilised

511 in adequate amounts, e.g. in large-scale biomass CHP plants which are common in

512 Denmark (straw-fired) and Sweden (wood fuel-fired) [27, 36, 61, 62]. The highest

513 energy quality is found in biogas vehicle fuel, which in this study has approx. $30 \%$

514 lower energy output per hectare than CHP from biomass. This option also had the

515 highest energy input of all four scenarios. The option with the lowest conversion

516 efficiency and the lowest energy output and NEY is CHP from biogas. This option only

517 makes sense for wet biomass sources where combustion is not an option, e.g. manure or

518 food wastes, but not for dedicated energy crops such as hemp or maize. Nonetheless,

519 electricity from biogas has become more common in Germany, where feed-in tariffs

520 render this option economically attractive, even though the combustion heat is often

521 only used for electricity production, i.e. the heat energy in the exhaust gases is not used

522 for heating purposes.

523 Bioethanol production from hemp was not investigated in the present study, since this is

524 an option with very high energy inputs [60]. Energy yields from combined bioethanol

525 production from hemp and biogas production from the stillage are only marginally

526 higher than that of direct biogas production from the same biomass [63], indicating that

527 an additional conversion process for bioethanol production seems to be rather

528 inefficient. 


\subsection{Importance of nutrient recycling}

Replacement of mineral fertiliser by digestate corresponded to a saving of $4.4 \%$ of the energy content of the biogas produced, including the energy inputs for storage, transport and spreading of the digestate. This confirms earlier findings (2-8\%) [40]. Ash recycling resulted in minor replacement of mineral fertiliser. In addition, ash utilisation as a fertiliser required a similar amount of energy, making this option less interesting from an energy balance point of view. However, in light of future phosphorus deposit depletion [64], recycling of ash is an important tool for closing nutrient cycles [65]. It has been shown that less than $100 \%$ of recycled nutrients are available to plants directly when spread on the field [60]. The present study did not address this issue, based on the assumption that fractions of nutrients (e.g. of P, K) not available to plants would replenish soil nutrient pools in the long-term. The content of micronutrients and organically-bound macronutrients $(\mathrm{N}, \mathrm{P}, \mathrm{K})$ was also not accounted for in the present study, but potentially leads to a long-term fertilisation effect. These findings support the concept that nutrient recycling can be important for the overall energy sustainability of biofuels from agricultural energy crops [60].

The present study employed the concept of recycling the same amount of nutrients (minus losses) as were removed with the biomass from the same area of land. This was done irrespective of potential national and regional restrictions as may apply for the utilisation of digestate and ash in agriculture, based on e.g. content of nutrients and heavy metals [66]. Although a detailed discussion of this topic was outside the scope of this paper, its importance for maintaining a healthy basis for agriculture must be recognised.

\subsection{Potential future hemp energy yield improvements}


555 Use of hemp as an energy crop started only recently with the establishment of new

556 cultivars with low THC content and the corresponding lifting of the ban on hemp

557 cultivation that existed in many European countries until the early 1990s [19].

558 Therefore, hemp has been developed little as an industrial crop over the past decades

559 [19]. In comparison to well-established (food) crops, hemp has great potential for

560 improvement, e.g. increased biomass yields or conversion efficiencies. Improvements in

561 harvesting technology could reduce harvesting losses, especially in spring harvesting of

562 dry hemp [67].

563 The low energy conversion efficiency from hemp biomass to biogas may indicate that

564 NEY can be increased by pretreatment of hemp biomass prior to anaerobic digestion,

565 e.g. grinding or steam explosion [63]. Combined steam and enzyme pretreatment of

566 biomass prior to anaerobic digestion could improve the methane potential of hemp by

567 more than 25\% [63]. Hydrolysis of maize and rye biomass with subsequent parallel

568 biogas and combustion processes resulted in around 7-13\% more energy output,

569 although energy input requirements were 4-5 times higher than when biomass was only

570 digested anaerobically [68]. Energy input for production of hemp biomass for both solid

571 biofuel and biogas purposes is relatively low, situated together with maize at the lower

572 end of the range for annual whole-crop plants [60]. Only perennial energy crops require

573 less average annual energy input over the life-time of the plantations. [60].

\subsection{Environmental impact}

576 The change in energy source for heating the biogas process in the vehicle fuel option

577 did not have a significant influence on NEY. However, the choice of external heat

578 source may have significant environmental effects. There is probably also a profound

579 economic effect, since heating fuels of lower energy quality (e.g. wood chips, straw or 
580

581

582

583

584

585

586

587

588

589

590

591

592

593

594

595

596

597

598

599

600

601

602

603

604

other agricultural residues) could be used for heating the biogas fermenter and about $5 \%$ more biogas could be upgraded to vehicle fuel. All scenarios examined here were characterised by high fossil energy input ratios. Fossil diesel accounted for more than $25 \%$ of the total energy input in all scenarios. In an environmental analysis, a change of fuel to renewable sources could potentially improve the carbon dioxide balance considerably.

Based on the energy balance for each scenario, the environmental influence of the energy utilisation of hemp can be evaluated, e.g. in a life cycle assessment (LCA).

LCAs have been reported for the production of hemp biomass [23], biodiesel [25] and electricity from hemp-derived biogas [24]. However, LCAs for other options such as large-scale combustion for CHP, heat from hemp briquettes or vehicle fuel from hempderived biogas are lacking.

\subsection{Competitiveness of hemp}

Hemp can become an interesting crop where other energy crops cannot be cultivated economically (e.g. maize, sugar beet and miscanthus further north in Sweden and other Nordic countries) or where an annual crop is preferred (e.g. to perennial willow, miscanthus or reed canary grass). Due to its advantages in the crop rotation (good weed competition) and marginal pesticide requirements, hemp can also be an interesting crop in organic farming.

Hemp as an energy crop can compete with other energy crops in a number of applications. For solid biofuel production, perennial energy crops, such as willow, miscanthus and reed canary grass, are the main competitors of agricultural origin. Willow and miscanthus have a substantially higher NEY than hemp, but are grown in perennial cultivation systems, binding farmers to the crop over approx. 10-20 years. To 
achieve a similarly high NEY for hemp, above-average biomass DM yields are required

606 and have been demonstrated on good soils [18].

607 For biogas production, maize and sugar beet are the main competitors. Maize and sugar

608

(1)
beet have often a similar or slightly higher biomass yield than hemp, but a substantially higher methane potential $[46,69]$. However, energy inputs for utilisation of sugar beet as biogas substrate are high, resulting in similar $\mathrm{R}_{\mathrm{O} / \mathrm{I}}$ to hemp. With increasing latitude of the cultivation site, the growing season becomes shorter and colder, which decreases the DM yield of maize ( $\mathrm{C}_{4}$-plant $)$ faster than that of hemp $\left(\mathrm{C}_{3}\right.$-plant $)$ [70]. This is reflected in commercial production in Sweden, where maize and sugar beet are grown up to latitudes of $60^{\circ} \mathrm{N}[1,70]$. Hemp can be grown even further north with good biomass yields [71].

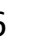

\section{Conclusions}

Hemp has high biomass DM and good net energy yields per hectare. Furthermore, hemp has good energy output-to-input ratios and is therefore an above-average energy crop. The combustion scenarios had the highest net energy yields and energy output-to-input ratios. The biogas scenarios suffer from higher energy inputs and lower conversion efficiencies but give higher quality products, i.e. electricity and vehicle fuel.

Hemp can be the best choice of crop under specific conditions and for certain applications. Advantages over other energy crops are also found outside the energy balance, e.g. low pesticide requirements, good weed competition and in crop rotations (annual cultivation). Future improvements of hemp biomass and energy yields may strengthen its competitive position against maize and sugar beet for biogas production and against perennial energy crops for solid biofuel production. 


\section{Role of Funding Source}

632 This study was financially supported by Partnership Alnarp at the Swedish University

633 of Agricultural Sciences, Environmental Fund of Region Skåne and Lunds Energi AB.

634 These funding sources did not have any involvement in study design, analysis and

635 interpretation of data, writing of this paper or the decision to submit the paper for

636 publication.

637

\section{References}

639 [1] Börjesson P. Bioenergi från jordbruket - en växande resurs. Stockholm, Sweden:

640 Jordbruksdepartementet - Statens Offentliga Utredningar; 2007. 496 p.

641 [2] EEA. Estimating the environmentally compatible bioenergy potential from agriculture.

642 Copenhagen, Denmark: European Environment Agency; 2007. 138 p.

643 [3] Hoogwijk M, Faaij A, Eickhout B, de Vries B, Turkenburg W. Potential of biomass

644 energy out to 2100, for four IPCC SRES land-use scenarios. Biomass Bioenerg; 2005; 29:225-57.

645 [4] Scharlemann JPW, Laurance WF. How green are biofuels? Science; 2008;

646 319(5859):43-4.

647 [5] Crutzen PJ, Mosier AR, Smith KA, Winiwarter W. $\mathrm{N}_{2} \mathrm{O}$ release from agro-biofuel

648 production negates global warming reduction by replacing fossil fuels. Atmos Chem Phys;

649 2008; 8:389-95.

650 [6] Zah R, Böni H, Gauch M, Hischier R, Lehmann M, Wägner P. Ökobilanz von

651 Energieprodukten - Ökologische Bewertung von Biotreibstoffen. St Gallen, Switzerland: Empa;

652 2007. $161 \mathrm{p}$.

653 [7] Börjesson P. Good or bad bioethanol from a greenhouse gas perspective - What

654 determines this? Appl Energy; 2009; 86(5):589-94.

655 [8] Börjesson P, Tufvesson LM. Agricultural crop-based biofuels - resource efficiency and

656 environmental performance including direct land use changes. J Cleaner Prod; 2011; 19(2-

657 3):108-20.

658 [9] Moerschner J, Gerowitt B. 6. Direct and indirect energy use in arable farming-an

659 example on winter wheat in Northern Germany. In: Weidema BP, Meeusen MJG, editors.

660 Agricultural data for Life Cycle Assessments. The Hague, The Netherlands: Agricultural

661 Economics Research Institute (LEI); 2000, p. 91-104

662 [10] Pimentel D. Ethanol fuels: energy balance, economics, and environmental impacts are

663 negative. Nat Resour Res; 2003; 12(2):127-34.

664 [11] Börjesson P. Energy analysis of biomass production and transportation. Biomass

665 Bioenerg; 1996; 11(4):305-18.

666 [12] Janulis P. Reduction of energy consumption in biodiesel fuel life cycle. Renew Energy;

667 2004; 29(6):861-71.

668 [13] Bernesson S. Hampa till bränsle, fiber och olja. Köping, Sweden: Sveriges

669 Energiföreningars Riksorganisation (SERO); 2006. 56 p.

670 [14] Sundberg M, Westlin H. Hampa som bränsleråvara. Uppsala, Sweden: JTI Institutet för 671 jordbruks- och miljöteknik; 2005. 32 p. 
672 [15] Mattsson JE. Affärsutveckling - Närodlade stråbränslen till kraftvärmeverk. Alnarp, 673 Sweden: Swedish University of Agricultural Sciences (SLU); 2006. 98 p.

674 [16] Kreuger E, Prade T, Escobar F, Svensson S-E, Englund J-E, Björnsson L. Anaerobic 675 digestion of industrial hemp-Effect of harvest time on methane energy yield per hectare.

676 Biomass Bioenerg; 2011; 35(2):893-900.

677 [17] Sipos B, Kreuger E, Svensson S-E, Rézcey K, Björnsson L, Zacchi G. Steam pretreatment 678 of dry and ensiled industrial hemp for ethanol production. Biomass Bioenerg; 2010; 679 34(12):1721-31.

680 [18] Prade T, Svensson S-E, Andersson A, Mattsson JE. Biomass and energy yield of 681 industrial hemp grown for biogas and solid fuel. Biomass Bioenerg; 2011; 35(7):3040-9.

682 [19] Bocsa I, Karus M. The Cultivation of Hemp: botany, varieties, cultivation and 683 harvesting. Sebastopol, USA: Hemptech; 1998. 184 p.

684 [20] Lotz LAP, Groeneveld RMW, Habekotte B, Oene H. Reduction of growth and 685 reproduction of Cyperus esculentus by specific crops. Weed Res; 1991; 31(3):153-60.

686 [21] Pimentel D. Handbook of energy utilization in agriculture. Boca Raton, USA: CRC Press, 687 Inc.; 1980.475 p.

688 [22] Forsberg M, Sundberg M, Westlin H. Småskalig brikettering av hampa. Uppsala, 689 Sweden: JTI Institutet för jordbruks- och miljöteknik; 2006. 34 p.

690 [23] van der Werf HMG. Life cycle analysis of field production of fibre hemp, the effect of production practices on environmental impacts. Euphytica; 2004; 140(1):13-23.

[24] Plöchl M, Heiermann M, Linke B, Schelle H. Biogas Crops - Part II: Balance of Greenhouse Gas Emissions and Energy from Using Field Crops for Anaerobic Digestion. Agric Eng Int: CIGR; 2009; XI:1-11.

[25] Casas XA, Rieradevall i Pons J. Environmental analysis of the energy use of hempanalysis of the comparative life cycle: diesel oil vs. hemp-diesel. Int J Agric Res Gov Ecol; 2005; 4(2):133-9.

698 [26] González-García S, Hospido A, Moreira MT, Feijoo G. Life Cycle Environmental Analysis 699 of Hemp Production for Non-wood Pulp, In: 3rd International Conference on Life Cycle 700 Management; 2007; Zürich, Switzerland. p. 1-6

701 [27] Hinge J. Elaboration of a Platform for Increasing Straw Combustion in Sweden, based on Danish Experiences. Stockholm, Sweden: Värmeforsk; 2009. 80 p.

[28] Bioenergiportalen. Hampa i Gudhem. http://www.bioenergiportalen.se/?p=1561\&pt=7. Uppsala, Sweden: JTI; 2007, accessed 201106-10

[29] Schüsseler P. Bedeutung des Sektors Biogas im Rahmen der Erneuerbaren Energien, In: Institut für Landtechnik und Tierhaltung F-W, Germany. Internationale Wissenschaftstagung Biogas Science 2009; 2009; Erding, Germany. Bayerische Landesanstalt für Landwirtschaft p. 920

[30] Börjesson P, Mattiasson B. Biogas as a resource-efficient vehicle fuel. Trends Biotechnol; 2008; 26(1):7-13.

[31] SCB. Normskördar för skördeområden, län och riket 2009. Jönköping, Sweden: Statistics Sweden; 2009. $66 \mathrm{p}$.

[32] SCB. Yearbook of agricultural statistics 2010. Jönköping, Sweden: Statistics Sweden; 2010. 390 p.

[33] SJV. Statistikdatabasen - Genomsnittlig areal (JEU), hektar per företag efter typgrupp/storleksklass.

http://www.jordbruksverket.se/swedishboardofagriculture.4.6621c2fb1231eb917e680002462 .html. Jönköping, Sweden: Swedish Board of Agriculture; 2008, accessed 2010-10-18

[34] SJV. Örebro, Sweden. Personal communication. 2010-10-14

[35] Festenstein GN, Lacey J, Skinner FA, Jenkins PA, Pepys J, Lacey J. Self-heating of hay and grain in Dewar flasks and the development of farmer's lung antigens. J Gen Microbiol; 1965; 41(3):389-407. 
[36] Sander B, Skøtt T. Bioenergy for electricity and heat - experiences from biomass-fired CHP plants in Denmark. Fredericia, Denmark: DONG Energy; 2007. 76 p. [37] Marmolin C, Ugander J, Gruvaeus I, Lundin G. Aska från halm och spannmål - kemisk sammansättning, fysikaliska egenskaper och spridningsteknik. Uppsala, Sweden: JTI - Swedish Institute of Agricultural and Environmental Engineering; 2008.

729 [38] Jonsson S. Hampabriketter. http://www.gudhemskungsgard.se/prod01.htm.

730 Falköping, Sweden: Gudhems Kungsgård; 2011, accessed 2011-06-29

731 [39] SEA. Produktion och använding av biogas år 2008. Eskilstuna, Sweden: Swedish Energy 732 Agency; 2010.

733 [40] Berglund M, Börjesson P. Assessment of energy performance in the life-cycle of biogas

[41] Börjesson P, Berglund M. Miljöanalys av biogassystem. Lund, Sweden: Department of Technology and Society, Lund University; 2003. 79 p.

[42] Lantz M, Ekman A, Börjesson P. Systemoptimerad production av fordonsgas. Lund, Sweden: Department of Technology and Society, Lund University; 2009. 110 p.

[43] Dalgaard T, Halberg N, Porter JR. A model for fossil energy use in Danish agriculture used to compare organic and conventional farming. Agric Ecosyst Environ; 2001; 87:51-65.

[44] Hülsbergen K-J, Feil B, Biermann S, Rathke G-W, Kalk W-D, Diepenbrock W. A method of energy balancing in crop production and its application in a long-term fertilizer trial. Agric Ecosyst Environ; 2001; 86:303-21.

[45] Scholz V, Berg W, Kaulfuß P. Energy balance of solid fuels. J Agric Eng Res; 1998; 71:263-72.

[46] Achilles A, Achilles W, Brenndörfer M, Einschütz K, Frisch J, Fritzsche S, et al. Betriebsplanung Landwirtschaft 2006/07. Darmstadt, Germany: KTBL; 2006. 672 p.

[47] Mikkola HJ, Ahokas J. Indirect energy input of agricultural machinery in bioenergy production. Renew Energy; 2009; 35(1):23-8.

[48] Börjesson P. Energianalyser av biobränsleproduktion i svenskt jord- och skogsbruk idag och kring 2015. Lund, Sweden: Department of Technology and Society, Lund University; 1994. $67 \mathrm{p}$.

[49] Hartmann D, Kaltschmitt M. Electricity generation from solid biomass via cocombustion with coal - Energy and emission balances from a German case study. Biomass Bioenerg; 1999; 16:397-406.

[50] Overend RP. The Average Haul Distance and Transportation Work Factors for Biomass Delivered to a Central Plant. Biomass; 1982; 2:75-9.

[51] SCB. El-, gas- och fjärrvärmeförsörjningen 2009. Stockholm, Sweden: Statistics Sweden; 2010. $24 \mathrm{p}$.

[52] Börjesson P, Berglund M. Environmental systems analysis of biogas systems - Part I: Fuel-cycle emissions. Biomass Bioenerg; 2006; 30(5):469-85.

[53] Benjaminsson J, Nilsson R. Distributionsformer för biogas och naturgas i Sverige. Stockholm, Sweden: Grontmij AB; 2009. 76 p.

[54] Energinet.dk. Gas in Denmark. Fredericia, Denmark: Energinet.dk; 2009. 72 p.

[55] Börjesson P, Gustavsson L. Regional production and utilization of biomass in Sweden. Energy; 1996; 21(9):747-64.

[56] Hagström P. Biomass potential for heat, electricity and vehicle fuel in Sweden. Vol. I. Uppsala, Sweden: Department of Bioenergy, Swedish University of Agricultural Sciences, 2006; 2006. 226 p.

[57] Heller MC, Keoleian GA, Volk TA. Life cycle assessment of a willow bioenergy cropping system. Biomass Bioenerg; 2003; 25(2):147-65.

[58] Caserini S, Livio S, Giugliano M, Grosso M, Rigamonti L. LCA of domestic and centralized biomass combustion: The case of Lombardy (Italy). Biomass Bioenerg; 2010; 34(4):474-82. 
[59] Uellendahl H, Wang G, Moller HB, Jorgensen U, Skiadas IV, Gavala HN, et al. Energy balance and cost-benefit analysis of biogas production from perennial energy crops pretreated by wet oxidation. Water Sci Technol; 2008; 58(9):1841-7.

778 [60] Scholz V, Heiermann M, Kaulfuss P. Sustainability of energy crop cultivation in Central 779 Europe. In: Lichtfouse E, editor. Sociology, Organic Farming, Climate Change and Soil Science 780 Springer; 2010, p. 109-45

781 [61] Björklund A, Niklasson T, Wahlén M. Biomass in Sweden:: Biomass-fired CHP plant in Eskilstuna. Refocus; 2001; 2(7):14-8.

783 [62] De S, Kaiadi M, Fast M, Assadi M. Development of an artificial neural network model 784 for the steam process of a coal biomass cofired combined heat and power (CHP) plant in Sweden. Energy; 2007; 32(11):2099-109.

[63] Kreuger E, Sipos B, Zacchi G, Svensson S-E, Björnsson L. Bioconversion of industrial hemp to ethanol and methane: The benefits of steam pretreatment and co-production. Bioresour Technol; 2011; 102(3):3457-65.

[64] Dawson CJ, Hilton J. Fertiliser availability in a resource-limited world: Production and recycling of nitrogen and phosphorus. Food Policy; 2011; 36(Supplement 1):S14-S22.

[65] Schröder JJ, Smit AL, Cordell D, Rosemarin A. Improved phosphorus use efficiency in agriculture: A key requirement for its sustainable use. Chemosphere; 2011; in press.

[66] Ottosson P, Bjurström H, Johansson C, Svensson S-E, Mattsson JE. Förstudie Halmaska i ett kretslopp. Stockholm, Sweden: Värmeforsk; 2009. 55 p.

[67] Svensson S-E, Prade T, Hallefält F, Mattsson JE. Utvädering av metoder för vårskörd av stråbränslen. Alnarp, Sweden: Swedish University of Agricultural Sciences (SLU), Department of Agriculture - Farming system, Technology and Product Quality; 2010. 32 p.

[68] Bühle L, Stülpnagel R, Wachendorf M. Comparative life cycle assessment of the integrated generation of solid fuel and biogas from biomass (IFBB) and whole crop digestion (WCD) in Germany. Biomass Bioenerg; 2011; 35(1):363-73.

[69] Heiermann M, PloechI M, Linke B, Schelle H, Herrmann C. Biogas Crops-Part I: Specifications and Suitability of Field Crops for Anaerobic Digestion. Agric Eng Int: CIGR; 2009; $\mathrm{XI}: 1-17$.

[70] Fogelfors H. Växtproduktion i jordbruket. Borås, Sweden: Natur och Kultur; 2001.

[71] Finell $M$, Xiong S, Olsson R. Multifunktionell industrihampa för norra Sverige. Uppsala, Sweden: Swedish University of Agricultural Sciences (SLU); 2006. 41 p.

[72] Davis J, Haglund C. Life cycle inventory (LCI) of fertiliser production - Fertiliser products used in Sweden and Western Europe. Gothenburg, Sweden: Chalmers University of Technology; 1999. 112 p.

[73] Kelm M, Wachendorf M, Trott H, Volkers K, Taube F. Performance and environmental effects of forage production on sandy soils. III. Energy efficiency in forage production from grassland and maize for silage. Grass Forage Sci; 2004; 59:69-79.

[74] Reinhardt GA. Energie- und CO2-Bilanzierung nachwachsender Rohstoffe. Brauschweig/Wiesbaden, Germany: Vieweg; 1993. 192 p.

[75] Bernesson S, Nilsson D, Hansson P-A. A limited LCA comparing large- and small-scale production of rape methyl ester (RME) under Swedish conditions. Biomass Bioenerg; 2004; 26:545-59.

[76] Börjesson P. Energianalys av drivmedel från spannmål och vall. Lund, Sweden: Department of Technology and Society. Lund University; 2004. 26 p.

[77] Scharmer K, Gosse G. Ecological impact of biodiesel production and use in europe, In: Moore A. Proceedings of the 2nd European Motor Biofuels Forum; 1996; Graz, Austria. p. 8-12 [78] EC. Proposal for a directive of the European parliament and of the council on the promotion of the use of energy from renewable sources. Commission of the European Communities; 2008. 
825 [79] Rosenberger A, Kaul HP, Senn T, Aufhammer W. Improving the energy balance of 826 bioethanol production from winter cereals: the effect of crop production intensity. Appl

827 Energy; 2001; 68(1):51-67.

828 [80] Smyth BM, Murphy JD, O'Brien CM. What is the energy balance of grass biomethane in 829 Ireland and other temperate northern European climates? Renew Sustain Energy Rev; 2009;

830 13(9):2349-60.

831 [81] Wells C. Total Energy Indicators of Agricultural Sustainability: Dairy Farming Case

832 Study. Otago, New Zealand: Department of Physics, University of Otago; 2001. 90 p.

833 [82] van Loo S, Koppejan J. The Handbook of Biomass Combustion and Co-firing. Sterling, 834 USA: Earthscan; 2008. 442 p.

835 [83] Focus_on_Nutrients. Nutrient balance calculator.

836 http://www.greppa.nu/vaxtnaringsbalans. Jönköping, Sweden: Swedish Board of Agriculture;

837 2011, accessed 2011-02-06

838 [84] Salter A, Banks CJ. Establishing an energy balance for crop-based digestion. Water Sci

839 Technol; 2009; 59(6):1053-60.

840 [85] Schittenhelm S. Chemical composition and methane yield of maize hybrids with 841 contrasting maturity. Eur J Agron; 2008; 29(2-3):72-9.

842 [86] Hartmann JK. Life-cycle-assessment of industrial scale biogas plants. Göttingen,

843 Germany: Faculty of Agricultural Sciences, University of Göttingen, 2006. 205 p.

844 [87] Pabón Pereira CP. Anaerobic digestion in sustainable biomass chains. Wacheningen,

845 The Netherlands: Centre for Sustainable Development and Food Security, University of

846 Wacheningen, 2009. $262 \mathrm{p}$.

847 [88] Loch V. Sechs Monate sind zu wenig. dlz Agrarmagazin. Munich, Germany; 2007, p. 56-

$848 \quad 8$.

849 [89] Bowers W. Agricultural field equipment. In: Fluck RC, editor. Energy in farm

850 production. Amsterdam, The Netherlands: Elsevier; 1992, p. 117-29 
Table 1. Primary energy factors and energy equivalents for the production means.

\begin{tabular}{lllccl}
\hline Item & Unit & \multicolumn{2}{c}{ Energy equivalent } & References \\
& & Value used & Literature low - high & \\
\hline Diesel fuel & energy content & $\mathrm{MJ} \mathrm{L}^{-1}$ & 37.4 & $35.9-38.7$ & {$[40,43,72-74]$} \\
& indirect energy use & $\mathrm{MJ} \mathrm{MJ}^{-1}$ & $0.19^{\mathrm{a}}$ & $0.10-0.27$ & {$[43,73-77]$} \\
Electricity & indirect energy use & $\mathrm{MJ} \mathrm{MJ}^{-1}$ & 1.20 & $1.12-1.92$ & {$[41,42,49,78]$} \\
& & & & \\
Mineral fertiliser & & & & \\
$\mathrm{N}$ & & & & \\
$\mathrm{P}$ & & & & & \\
$\mathrm{KJ} \mathrm{kg}$ & $\mathrm{MJ} \mathrm{kg}^{-1}$ & $25.0^{\mathrm{b}}$ & $7.9-70.0$ & {$[11,40,43,74,79-81]$} \\
Seeds & $\mathrm{MJ} \mathrm{kg}^{-1}$ & $5.0^{\mathrm{b}}$ & $4.8-12.6$ & {$[11,40,43,74,79-81]$} \\
\hline
\end{tabular}

${ }^{\mathrm{a}} 0.04 \mathrm{MJ} \mathrm{MJ}^{-1}$ for lubricants and $0.15 \mathrm{MJ} \mathrm{MJ}^{-1}$ for the manufacturing process.

${ }^{\mathrm{b}}$ These values reflect the current trend of increasing energy efficiency in nitrogen fertiliser production and increasing energy demand for phosphorus fertiliser production [8].

${ }^{\mathrm{c}}$ Based on the assumption of $7.5 \mathrm{MJ} \mathrm{kg}^{-1}$ for the production of the seeds, $0.6 \mathrm{MJ} \mathrm{kg}^{-1}$ for coating [81] and $2.0 \mathrm{MJ} \mathrm{kg}^{-1}$ for the transport (France-Sweden (1800 km at $1.1 \mathrm{~kJ} \mathrm{~kg}^{-1} \mathrm{~km}^{-1}$ [80]). 
Table 2. Assumed values for parameters used for calculation of the energy balance of hemp biomass production and utilisation as biogas substrate or solid biofuel, respectively. See section 2.2 for description of scenarios. Roman numerals indicate corresponding scenarios.

\begin{tabular}{|c|c|c|c|c|}
\hline \multirow[t]{2}{*}{ Parameter } & \multirow[t]{2}{*}{ Unit } & \multicolumn{2}{|c|}{ Application of biomass as } & \multirow[t]{2}{*}{ References } \\
\hline & & Solid biofuel & Biogas substrate $^{a}$ & \\
\hline Scenarios & & I and II & III and IV & \\
\hline \multicolumn{5}{|l|}{ Cultivation } \\
\hline $\mathrm{N}$ fertilisation ${ }^{\mathrm{b}}$ & $\mathrm{kg} \mathrm{ha}^{-1}$ & 150 & $150(81)$ & {$[14,19]$} \\
\hline $\mathrm{P}$ fertilisation ${ }^{\mathrm{c}}$ & $\mathrm{kg} \mathrm{ha}^{-1}$ & 10 & $35(32)$ & Unpublished results \\
\hline $\mathrm{K}$ fertilisation ${ }^{\mathrm{c}}$ & $\mathrm{kg} \mathrm{ha}^{-1}$ & 8 & $123(188)$ & Unpublished results \\
\hline Seeds & $\mathrm{kg} \mathrm{ha}^{-1}$ & 20 & 20 & {$[18]$} \\
\hline \multicolumn{5}{|l|}{ Biomass } \\
\hline Harvest period & & February to April & September to October & {$[18]$} \\
\hline Harvest losses & $\%$ & 25 & 10 & [18] \\
\hline DM yield (after harvest losses) & $\mathrm{Mg} \mathrm{ha}^{-1}$ & 6.1 & 10.3 & [18] \\
\hline Moisture content & $\%$ & 15 & 65 & {$[18]$} \\
\hline Specific methane yield & $\mathrm{Nm}^{3} \mathrm{~kg}_{\mathrm{VS}}{ }^{-1 \mathrm{~d}}$ & n.a. & 0.21 & {$[16,24]$} \\
\hline Volatile solids content & $\%_{\mathrm{DM}}$ & n.a. & 93 & [16] \\
\hline $\mathrm{HHV}^{\mathrm{e}}$ & $\mathrm{MJ} \mathrm{kg}^{-1}$ & 19.1 & 18.4 & [18] \\
\hline $\mathrm{LHV}^{\mathrm{f}}$, dry basis & $\mathrm{MJ} \mathrm{kg}^{-1}$ & 17.4 & 12.6 & [18] \\
\hline \multicolumn{5}{|l|}{ Model } \\
\hline Average field size & ha & 4 & 4 & [34] \\
\hline \multicolumn{5}{|l|}{ Average transport distance } \\
\hline field $\rightarrow$ farm storage (bales, bulk) & $\mathrm{km}$ & 4 & n.a. & [46] \\
\hline $\begin{array}{l}\text { farm storage } \rightarrow \text { CHP plant (bales) } \\
\text { CHP plant } \rightarrow \text { farm (ash) }\end{array}$ & $\mathrm{km}$ & $40(\mathrm{I})$ & n.a. & Own calculations, section 2.4 \\
\hline farm storage $\rightarrow$ petrol station/bulk costumer (briquettes) & $\mathrm{km}$ & 30 (II) & n.a. & Own calculations, section 2.4 \\
\hline $\begin{array}{l}\text { field } \rightarrow \text { biogas plant (bulk), } \\
\text { biogas plant } \rightarrow \text { field (digestate) }\end{array}$ & $\mathrm{km}$ & n.a. & 15 & Own calculations, section 2.4 \\
\hline
\end{tabular}

\section{n.a. = not applicable}

${ }^{a}$ Number in brackets refers to the amount of N, P and K, respectively, derived from the recycling of digestate as biofertiliser. Note that recycling rates for potassium are higher than removal rates by hemp biomass, due to higher potassium removal rates by maize biomass, which accounts for $76 \%$ of the recycled digestate. Recycling was only accounted for up to $100 \%$ of the removal rates.

$\mathrm{b}$ The total nitrogen fertilisation level was assumed to be a fixed amount to ensure crop growth.

${ }^{\mathrm{c}}$ Phosphorus and potassium fertilisation levels adjusted to the amount of nutrient removal.

${ }^{\mathrm{d}} \mathrm{Nm}^{3}=$ normal cubic meters, refer to gas volumes standardised at $273 \mathrm{~K}$ and $100 \mathrm{kPa}$. VS = volatile solids.

${ }^{\mathrm{e}} \mathrm{HHV}=$ higher heating value

${ }^{\mathrm{f}} \mathrm{LHV}=$ lower heating value 
Table A.1. Assumed and calculated process parameters used for modelling the CHP plant.

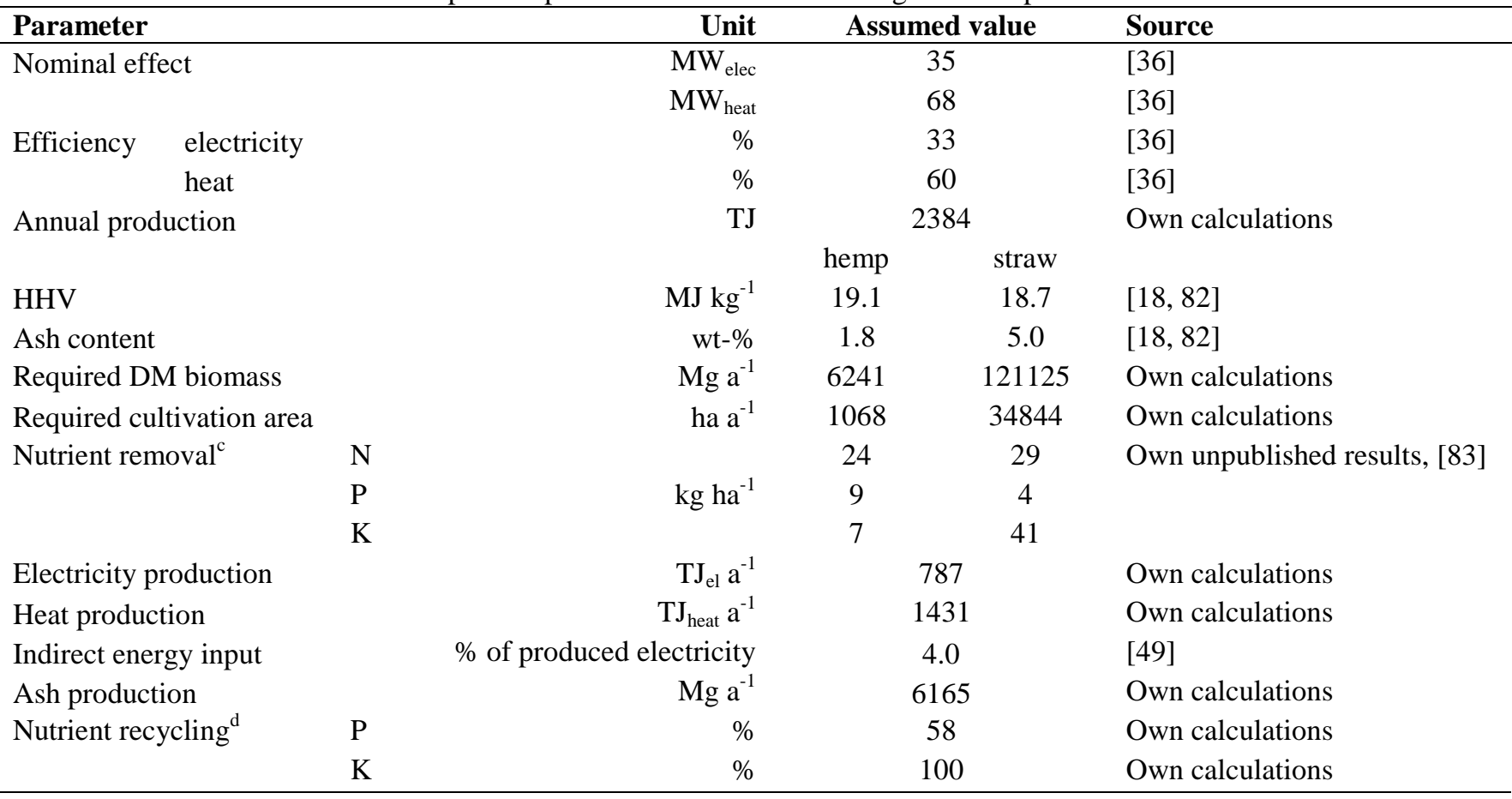


Table A.2. Assumed and calculated process parameters used for modelling the anaerobic digestion plant. The tables

list the major direct and indirect energy inputs.

\section{Parameter}

Digester, size ${ }^{\mathrm{a}}$

Unit Assumed value

\section{References}

Storage tank for digestate, size

Feed

$\mathrm{m}^{3} \quad 2600$

Own calculations

\section{Own calculations}

Required DM biomass

Required cultivation area

Specific methane yield

Volatile solids content

Nutrient removal ${ }^{\mathrm{c}}$

\begin{tabular}{rrr}
$\mathrm{m}^{3}$ & \multicolumn{2}{c}{14500} \\
$\mathrm{~kg}_{\mathrm{VS}} \mathrm{m}^{-3} \mathrm{~d}^{-1}$ & \multicolumn{2}{c}{3.0} \\
& hemp & maize \\
$\mathrm{Mg} \mathrm{a}^{-1}$ & 2218 & 6377
\end{tabular}

$\mathrm{P}$

Nutrient recycling

ha a $^{-1} \quad 215 \quad 531$

6377 Own calculations

$\mathrm{Nm}_{\mathrm{CH} 4}^{3} \mathrm{~kg}_{\mathrm{VS}}{ }^{-1} \quad 0.21 \quad 0.32 \quad[16,24,85]$

$\%_{\text {DM }} \quad 93 \quad 95 \quad[16,85]$

$\mathrm{kg} \mathrm{ha}^{-1} \quad 35$

$83 \quad 154$

$\mathrm{P}$

Life time digester and storage

\section{Direct energy input}

Heating
pumping \& mixing

Indirect energy input

Anaerobic digester

Digestate storage

$35 \quad 31$

Own unpublished results, [18, 83]

$121 \quad 216$

$\% \quad 92$

92

100

Own calculations

a 20

ant (scenario III)

${ }^{\mathrm{a}}$ Two units of $1300 \mathrm{~m}^{3}$ each.

${ }^{\mathrm{b}}$ Five units of $2900 \mathrm{~m}^{3}$ each, dimensioned for the storage capacity for digestate accumulated over 8 months [88].

${ }^{c}$ Based on a normalised yield for hemp and maize.

${ }^{\mathrm{d}}$ Calculated from $15 \%$ losses during digestion and spreading and a share of $\mathrm{NH}_{4}-\mathrm{N}$ of $74 \%$ according to the degree

of mineralisation during the digestion process.

${ }^{\mathrm{e}}$ Indirect energy inputs from transport and assembly of building materials were assumed to be minor and were not accounted for. For simplicity, building materials included only steel, concrete and plastics, assuming a steel digestion reactor and a steel reinforced concrete tank with plastic gastight roofing for storage of digestate.

$\mathrm{DM}=$ dry matter 
Table A.3. Machinery specifications as used in the present study.

\begin{tabular}{|c|c|c|c|c|c|c|c|c|c|}
\hline Operation & Machine type & $\begin{array}{l}\text { Working } \\
\text { width } \\
\text { [m] }\end{array}$ & $\begin{array}{c}\text { Weight } \\
{[\mathrm{kg}]}\end{array}$ & $\begin{array}{c}\text { Power/power } \\
\text { requirement } \\
{[\mathrm{kW}]}\end{array}$ & $\begin{array}{c}\text { Diesel } \\
\text { consumption } \\
{\left[\mathrm{L} \mathrm{ha}^{-1}\right]} \\
\end{array}$ & $\begin{array}{c}\text { Annual } \\
\text { use } \\
{\left[\mathrm{h} \mathrm{a}^{-1}\right]}\end{array}$ & $\begin{array}{c}\text { Scenario } \\
\text { use }^{\mathrm{b}} \\
{\left[\mathrm{h} \mathrm{ha}^{-1}\right]}\end{array}$ & $\begin{array}{c}\text { Lifetime } \\
{[a]} \\
\end{array}$ & $\begin{array}{c}\text { Indirect } \\
\text { energy }^{c} \\
{[\mathrm{GJ}]}\end{array}$ \\
\hline \multicolumn{10}{|l|}{ Cultivation (all scenarios) } \\
\hline Ploughing & 4 furrow plough & 1.4 & 1280 & 88 & 22.9 & 180 & 1.8 & 10 & 51 \\
\hline Seedbed preparation & Harrow combination & 6.0 & 2500 & 77 & 5.7 & 90 & 0.4 & 12 & 99 \\
\hline Sowing / fertilisation & Seeding combination & 3.0 & 2700 & 88 & 9.4 & 125 & 1.0 & 10 & 98 \\
\hline \multicolumn{10}{|c|}{ Spring harvest (as bales), scenario I } \\
\hline Cutting \& swathing & Windrower & 4.5 & 5560 & 97 & 10.4 & 200 & 1.5 & 10 & 240 \\
\hline Baling & Square baler & 3.0 & 9830 & 112 & 6.8 & 225 & 0.5 & 10 & 333 \\
\hline Loading and transport to farm & Wagon train & n.a. & 5500 & 102 & 3.7 & 200 & 0.9 & 10 & 197 \\
\hline Storage in plastic wrapping & Bale wrapper & n.a. & 4536 & 14 & 3.6 & 250 & 0.4 & 10 & 200 \\
\hline Loading of bales & Tractor with fork & n.a. & 7000 & 100 & 0.5 & 850 & 0.9 & 12 & 309 \\
\hline Transport to CHP plant & Truck with trailer & n.a. & 15800 & 243 & 20.6 & $10^{6 \mathrm{~d}}$ & $41.0^{\mathrm{e}}$ & 10 & 683 \\
\hline \multicolumn{10}{|c|}{ Spring harvest (as bulk material) ( scenario II) } \\
\hline Cutting and chopping & Forage harvester & 4.5 & 13240 & 458 & 15.2 & 400 & 0.5 & 10 & 510 \\
\hline $\begin{array}{l}\text { Collecting and transport to } \\
\text { farm }\end{array}$ & Forage wagon & n.a. & 6500 & 88 & 2.5 & 150 & 1.1 & 10 & 233 \\
\hline Storage & $\begin{array}{l}\text { Tractor -driven tube } \\
\text { press }\end{array}$ & n.a. & 7000 & 147 & 15.9 & 210 & 0.2 & 12 & 261 \\
\hline Unloading / press feed & Front loader & n.a. & 13500 & 105 & 2.5 & 350 & 1.1 & 10 & 520 \\
\hline Briquette production & Briquette press & n.a. & 2800 & 11 & $15^{\mathrm{f}}$ & 1349 & 36 & 10 & 124 \\
\hline Transport to sales place & Truck with trailer & n.a. & 15800 & 243 & 5.8 & $10^{6 \mathrm{~d}}$ & $11.5^{\mathrm{e}}$ & 10 & 683 \\
\hline \multicolumn{10}{|c|}{ Autumn harvest (as bulk material) (scenarios III and IV) } \\
\hline Cutting and chopping & Forage harvester & 4.5 & 13240 & 458 & 21.1 & 400 & 0.7 & 10 & 510 \\
\hline
\end{tabular}


Collecting and transport to biogas plant

Unloading / tube press feed Storage

Unloading / biogas plant feed

Transport of digestate to field

Spreading of digestate
Truck with dumper

trailer

Front loader

Tractor -driven tube

ensiling

Front loader

Truck with tank trailer

Tractor with drag hose

trailer

n.a. $\quad 15246$

n.a. $\quad 13500$

n.a. $\quad 7000$

105

147

n.a. $\quad 13500$

n.a. 12520

$12 \quad 4300$

105

295

200

n.a.

6000

9500

88

200

n.a. ${ }^{\mathrm{g}}$

n.a. ${ }^{\mathrm{g}}$

650

850

n.a. ${ }^{\mathrm{h}}$

230

For harvest, transport and

Tractor

n.a.

storage operations

n.a. = not applicable

${ }^{a}$ Powering soil treatment operations assumed use of a $88 \mathrm{~kW}$ tractor. Powering of harvest, transport and storage operations assumed use of a $200 \mathrm{~kW}$ tractor.

${ }^{\mathrm{b}}$ For hemp biomass production.

${ }^{c}$ Total lifetime indirect energy including, material, manufacture and maintenance. Calculated after [48, 89] with energy coefficients for steel (17.5 $\left.\mathrm{MJ}^{\mathrm{kg}}{ }^{-1}\right)$, cast iron (10.0 MJ kg ${ }^{-1}$ ) and tyres (85 $\left.\mathrm{MJ} \mathrm{kg}^{-1}\right)$. Repair multipliers are taken from [48].

${ }^{\mathrm{d}}$ Unit: km

${ }^{\mathrm{e}}$ Unit: $\mathrm{km} \mathrm{ha}^{-1}$

${ }^{\mathrm{f}}$ Unit: kWh

${ }^{\mathrm{g}}$ Included in the respective field operation.

${ }^{\mathrm{h}}$ See respective field operation. 
1

Table A.4. Direct and indirect energy input of fertilisation, field operations, transport and intermediate storage.

\begin{tabular}{|c|c|c|c|c|c|c|c|c|c|}
\hline & & \multicolumn{4}{|c|}{ Energy input - solid biofuel - scenarios $I$ and $I I$} & \multicolumn{4}{|c|}{ Energy input - biogas - scenarios $I I I$ and $I V$} \\
\hline & & \multicolumn{2}{|c|}{ Direct $^{\mathrm{a}}$} & \multirow{2}{*}{$\frac{\text { Indirect }}{\left(\mathrm{MJ} \mathrm{ha}^{-1} \mathrm{y}^{-1}\right)}$} & \multirow{2}{*}{$\frac{\text { Total }}{\left(\mathrm{MJ} \mathrm{ha}^{-1} \mathrm{y}^{-1}\right)}$} & \multicolumn{2}{|c|}{ Direct $^{\mathrm{a}}$} & \multirow{2}{*}{$\frac{\text { Indirect }}{\left(\mathrm{MJ} \mathrm{ha}^{-1} \mathrm{y}^{-1}\right)}$} & \multirow{2}{*}{$\frac{\text { Total }}{\left(\mathrm{MJ} \mathrm{ha}^{-1} \mathrm{y}^{-1}\right)}$} \\
\hline Production mea & & $\left(\mathrm{kg} \mathrm{ha}^{-1}\right)$ & & & & $\left(\mathrm{kg} \mathrm{ha}^{-1}\right)$ & & & \\
\hline Mineral fertiliser & $\mathrm{N}$ & 150 & & 6750 & 6750 & 67 & & 3009 & 3009 \\
\hline & $\mathrm{P}($ scenario I/II $)$ & $9 / 6$ & & $64 / 104$ & $64 / 104$ & 3 & & 29 & 29 \\
\hline & $\mathrm{K}$ (scenario I/II) & $7 / 0$ & & $0 / 30$ & $0 / 30$ & 0 & & 0 & 0 \\
\hline Seeds & & 20 & & 270 & 270 & 20 & & 270 & 270 \\
\hline Field / transport & toperation & $\left(\mathrm{Lha}^{-1} \mathrm{y}^{-1}\right)$ & $\left(\mathrm{MJ} \mathrm{ha}^{-1} \mathrm{y}^{-1}\right)$ & $\left(\mathrm{MJ} \mathrm{ha}^{-1} \mathrm{y}^{-1}\right)$ & $\left(\mathrm{MJ} \mathrm{ha}^{-1} \mathrm{y}^{-1}\right)$ & $\left(\mathrm{Lha}^{-1} \mathrm{y}^{-1}\right)$ & $\left(\mathrm{MJ} \mathrm{ha}^{-1} \mathrm{y}^{-1}\right)$ & $\left(\right.$ MJ ha $\left.^{-1} y^{-1}\right)$ & $\left(\mathrm{MJ} \mathrm{ha}^{-1} \mathrm{y}^{-1}\right)$ \\
\hline Stubble treatmen & & 8.6 & 322 & 97 & 419 & 8.6 & 322 & 97 & 419 \\
\hline Ploughing & & 22.9 & 856 & 278 & 1134 & 22.9 & 856 & 278 & 1134 \\
\hline Seedbed preparat & & 5.7 & 213 & 96 & 309 & 5.7 & 213 & 96 & 309 \\
\hline Sowing / fertilisi & ng combination & 9.4 & 352 & 177 & 528 & 9.4 & 352 & 177 & 528 \\
\hline Ash / digestate sp & oreading incl. transport etc. (scenario I/II) & $1.0 / 0$ & $37 / 0$ & $15 / 0$ & $52 / 0$ & 24.0 & 902 & 665 & 1567 \\
\hline Compaction & & 3.6 & 135 & 123 & 258 & 3.6 & 135 & 123 & 258 \\
\hline \multicolumn{10}{|c|}{ Bale storage line $^{\mathrm{b}}-($ scenario I $)$} \\
\hline Swathing & & 10.1 & 377 & 244 & 621 & & & & \\
\hline Loading/trans & sport/unloading field-farm & 3.5 & 131 & 150 & 281 & & & & \\
\hline Storage in pla & astic film & 3.6 & 135 & $471^{\mathrm{d}}$ & 606 & & & & \\
\hline \multicolumn{10}{|c|}{ Bulk storage line $^{c}-($ scenarios II, left; III and IV, right) } \\
\hline Cutting and $\mathrm{c}$ & hopping & 15.1 & 566 & 168 & 734 & 21.0 & 787 & 234 & 1022 \\
\hline Collecting an & d transport & 2.4 & 90 & 211 & 301 & 28.8 & 1075 & 242 & 1317 \\
\hline Ensiling/stora & gge in tube baler & 15.7 & 588 & $1564^{\mathrm{e}}$ & 2152 & 17.5 & 654 & $1636^{\mathrm{f}}$ & 2290 \\
\hline Total - bale stora & ge line (scenario I) & 75.0 & 2803 & 8875 & 11679 & & & & \\
\hline Total - bulk store & age line (scenarios II, left; III and IV, right) & 83.5 & 3122 & 9867 & 12989 & 141.5 & 5295 & 6856 & 12151 \\
\hline
\end{tabular}


${ }^{\mathrm{a}}$ Data on diesel consumption calculated from [46].

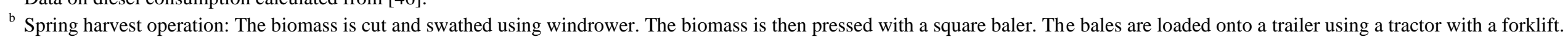

${ }^{c}$ Autumn and spring harvest operation: The biomass is cut and chopped using a conventional forage harvester. The chopped biomass is blown into a tractor-wagon combination.

${ }^{\mathrm{d}}$ Includes $414 \mathrm{MJ} \mathrm{ha}^{-1}$ for plastic wrapping for storage.

${ }^{\mathrm{e}}$ Includes $1432 \mathrm{MJ} \mathrm{ha}^{-1}$ for plastic tube for storage.

${ }_{\mathrm{f}}^{\mathrm{f}}$ Includes $1415 \mathrm{MJ} \mathrm{ha}^{-1}$ for plastic tube for ensiling/storage 
1 Fig. 1. Schematic overview of the field and transport operations accounted for in CHP

2 production from baled hemp (scenario I), heat production from briquetted hemp

3 biomass (scenario II), CHP production from hemp-derived biogas (scenario III) and

4 vehicle fuel production from hemp-derived biogas (scenario IV).

5

6 Fig. 2. Schematic overview of the anaerobic digestion (AD) process and the subsequent

7 utilisation of biogas for base scenario III (top). The centre panel depicts the pathway

8 without (base scenario IV) and with an additional upgrading option from 97\% methane

9 content to NGQ vehicle fuel (subscenario, grey items). The bottom panel depicts the

subscenarios using external heat for the $\mathrm{AD}$ process with and without the same upgrading option (grey items).

Fig. 3. Energy inputs according to production means (left part of columns) and process stage (right part of columns) for scenarios I to IV. Energy inputs are given for hemp biomass production up to intermediate storage (top) and up to final energy product (bottom).

Fig. 4. Energy output (white), energy inputs (grey) and net energy yields (black) for scenarios I to IV. Output energy shows heat, power and vehicle fuel production from hemp biomass.

Fig. 5. Energy output-to-input ratio $\left(\mathrm{R}_{\mathrm{O} / \mathrm{I}}\right)$ and net energy yield $(\mathrm{NEY})$ as influenced by the biomass DM yield of hemp. Harvest losses of $25 \%$ for harvest as solid biofuel and $10 \%$ for harvest as biogas substrate [18] were subtracted from the biomass yield.

Fig. 6. Sensitivity analysis for scenarios I to IV. Variation of the energy input/output ratio by changing biomass yield, transportation distance and diesel consumption. NEY = net energy yield.

Fig. 7. Sensitivity analysis for scenario IV. Variation of the energy input/output ratio by changing heat and electricity source and upgrading quality. BS = base scenario. NEY = net energy yield. 
1 Fig. 8. Net energy yield for biomass energy content at intermediate storage (top), heat, 2 electricity and CHP from biomass (centre) and raw biogas, electricity from biogas and 3 upgraded biogas (bottom). Black columns denote data for hemp from the present study, 4 both the base scenario (BS) and the subscenario $+30 \%$ biomass. Grey columns denote 5 published data. White columns indicate the corresponding energy output. The 6 corresponding output-to-input ratio $\left(\mathrm{R}_{\mathrm{O} / \mathrm{I}}\right)$ is shown above each column. 


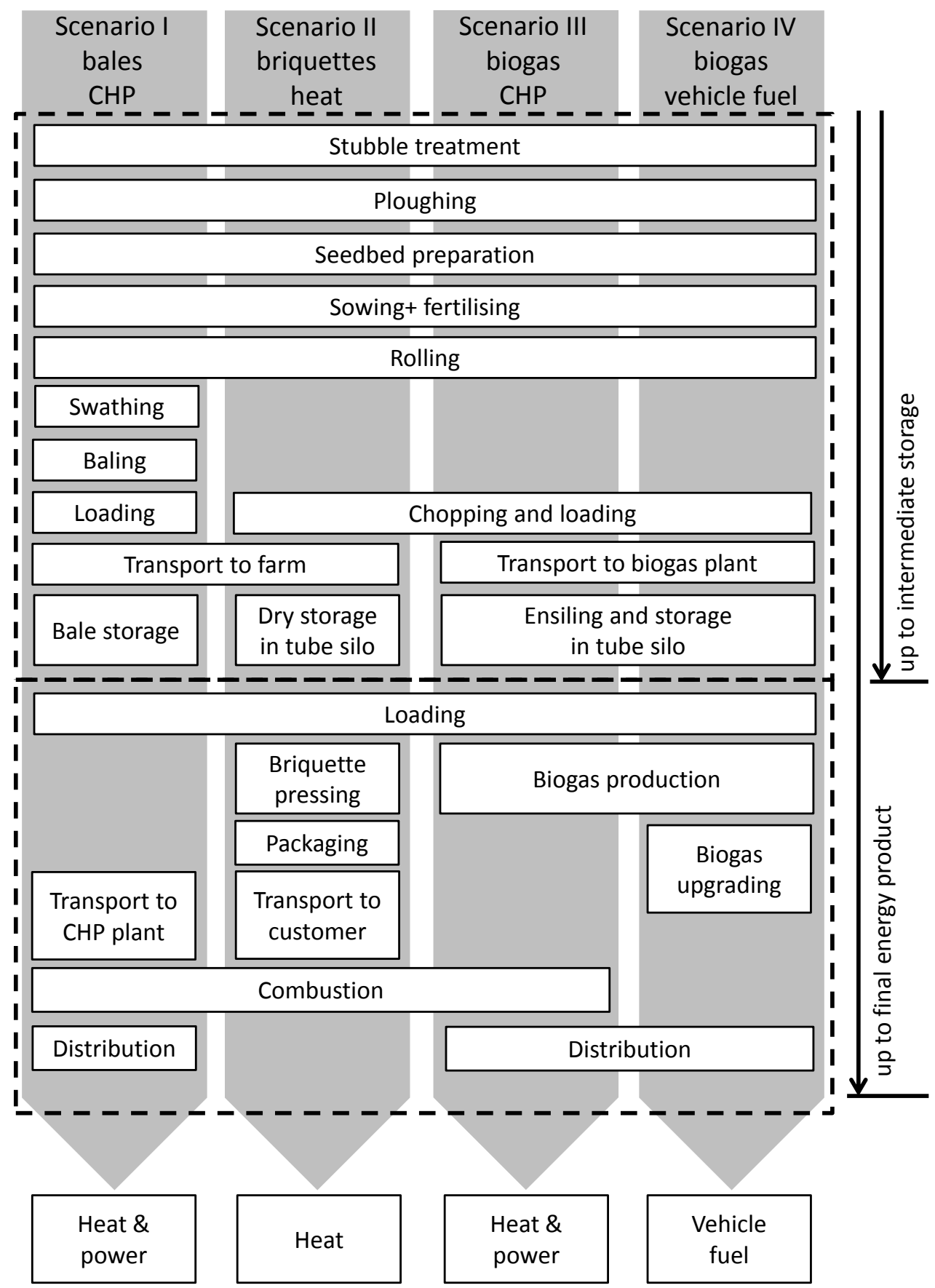

3

File: 20110704 Energy balance system boundaries 


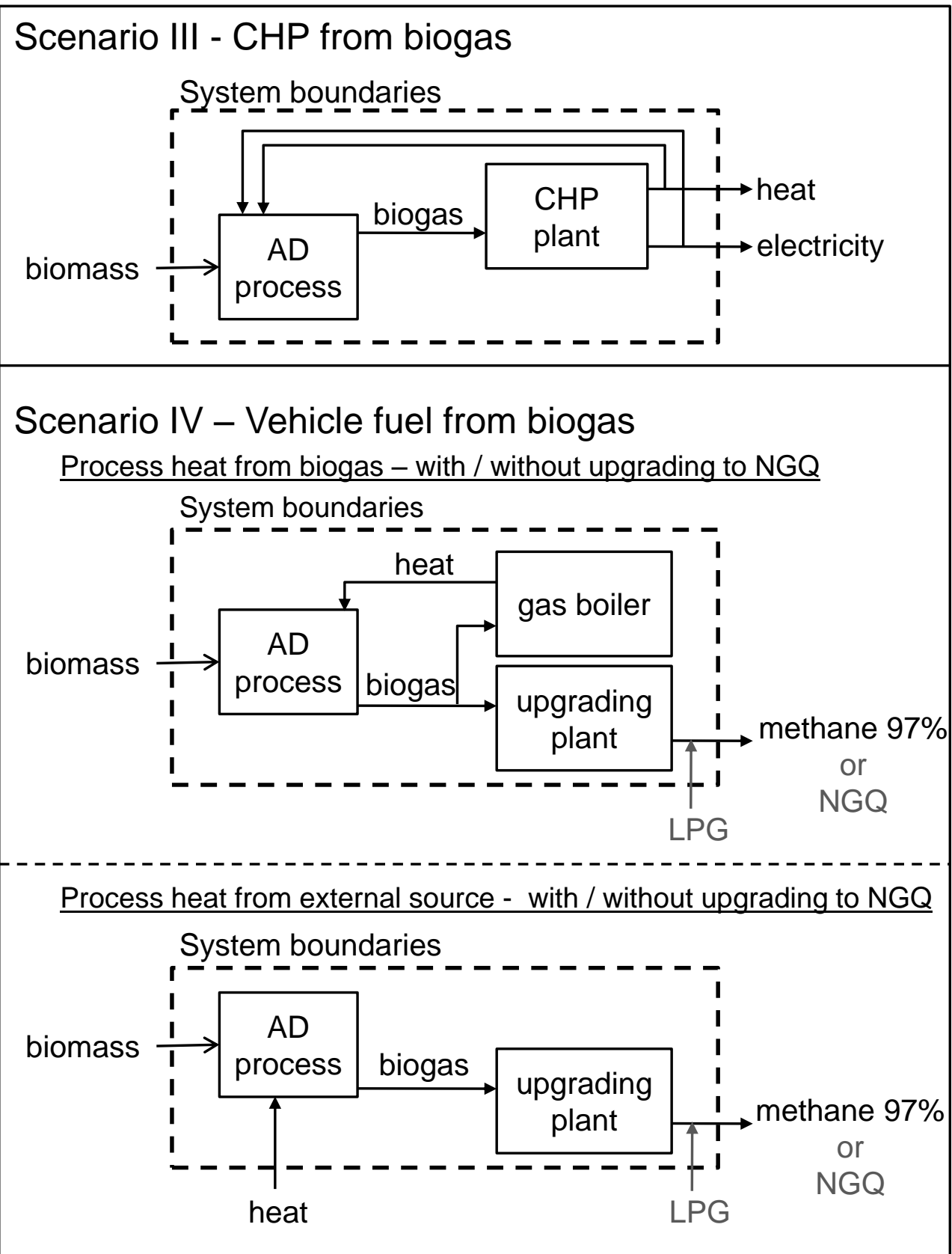



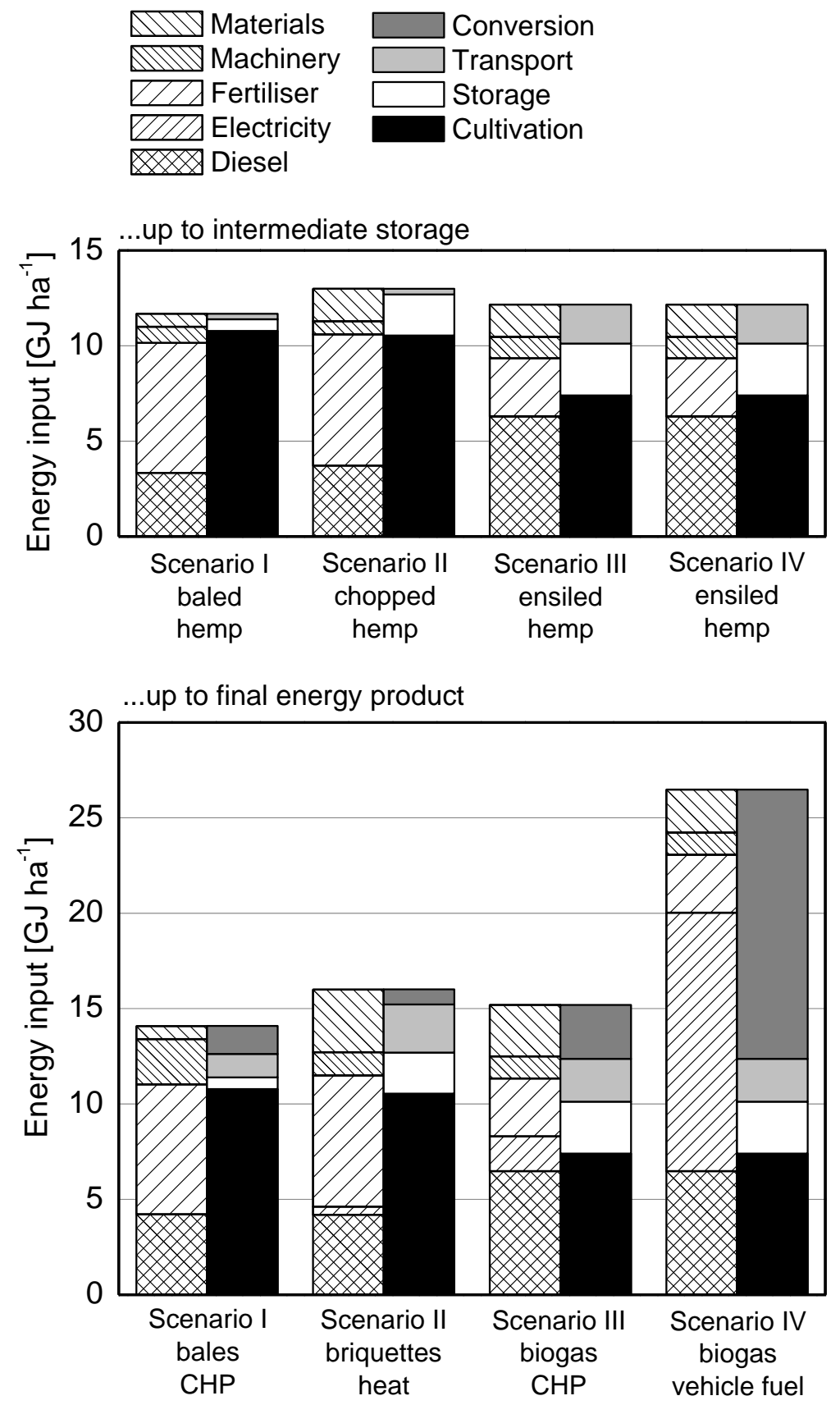

3

4

5

File: 20110704 Comparison Scenarios Energy input 


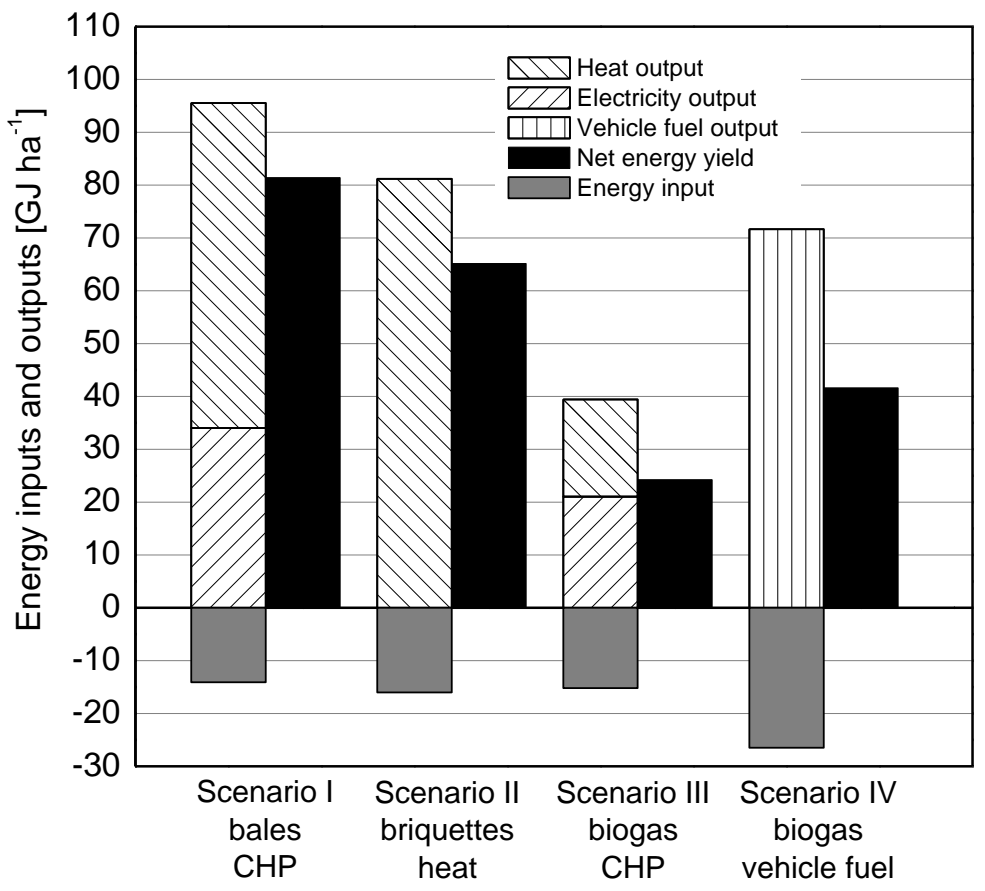

File: 20110623 Energy - net and inputs 
Fig. 5
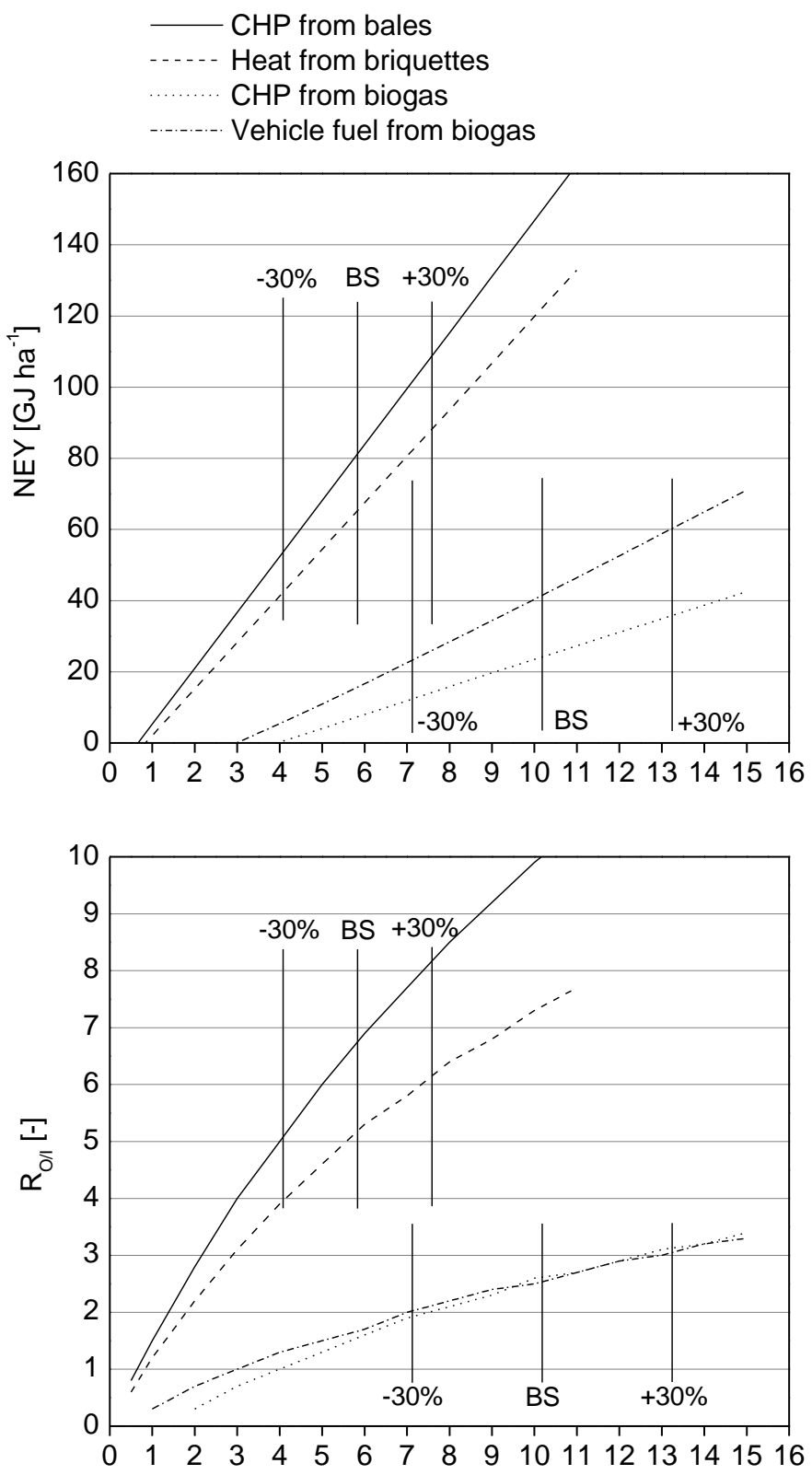

Dry matter yield [Mg ha ${ }^{-1}$ ]

3

4

5

6

7

8 
2 Fig. 6

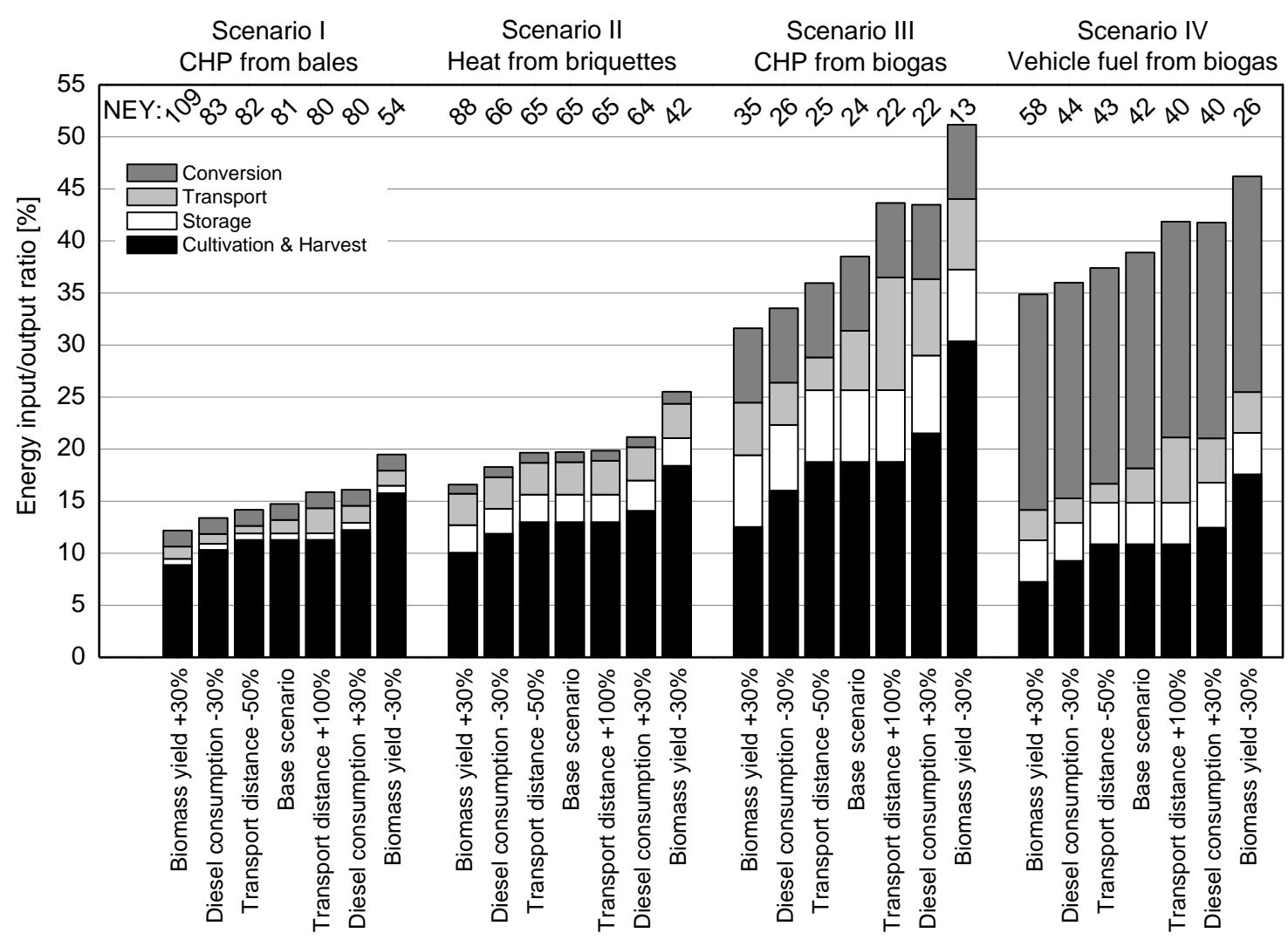

3

File: 20110623 Comparison scenarios and subscenarios 
2 Fig. 7.

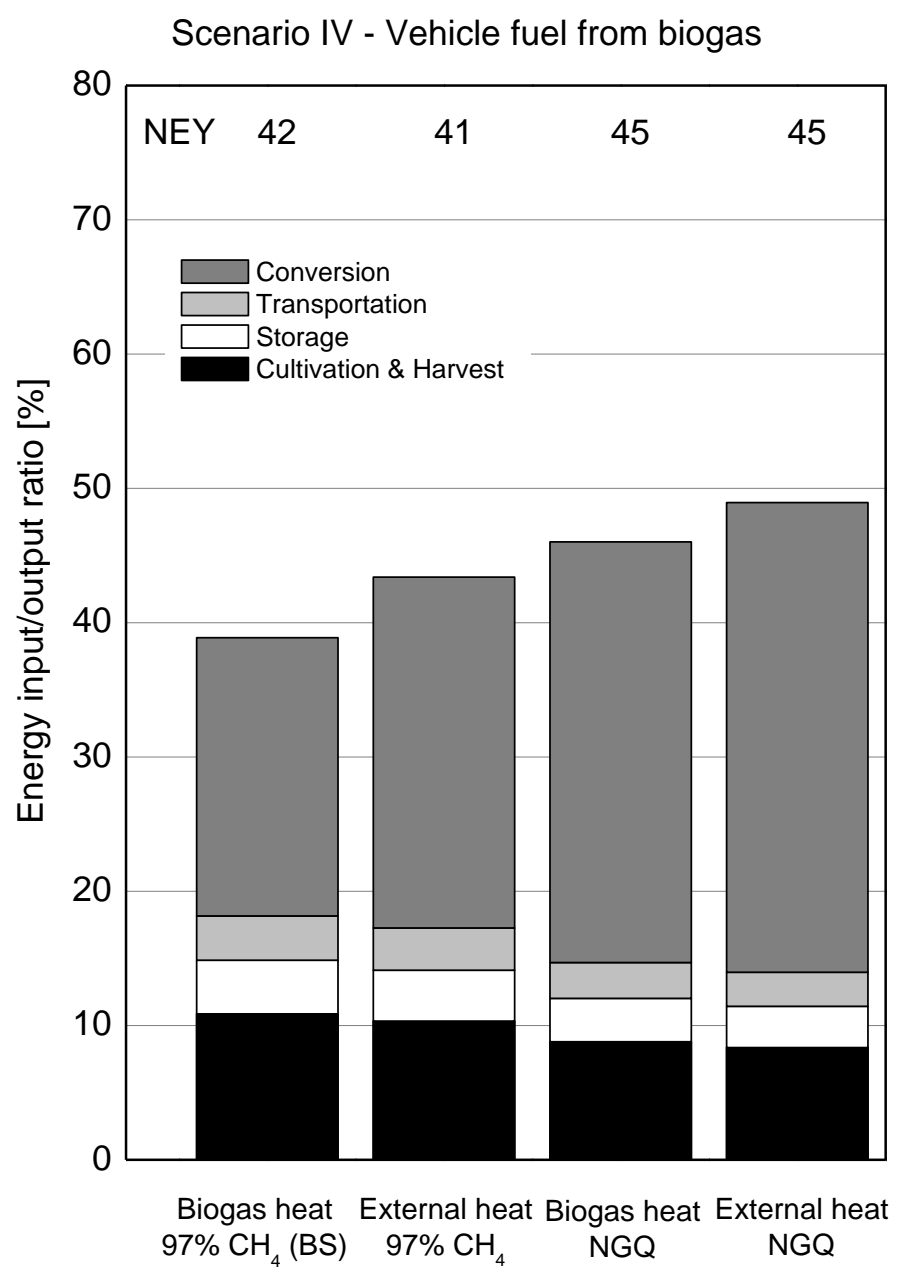

3

File: 20110623 Comparison scenarios and subscenarios2

5 

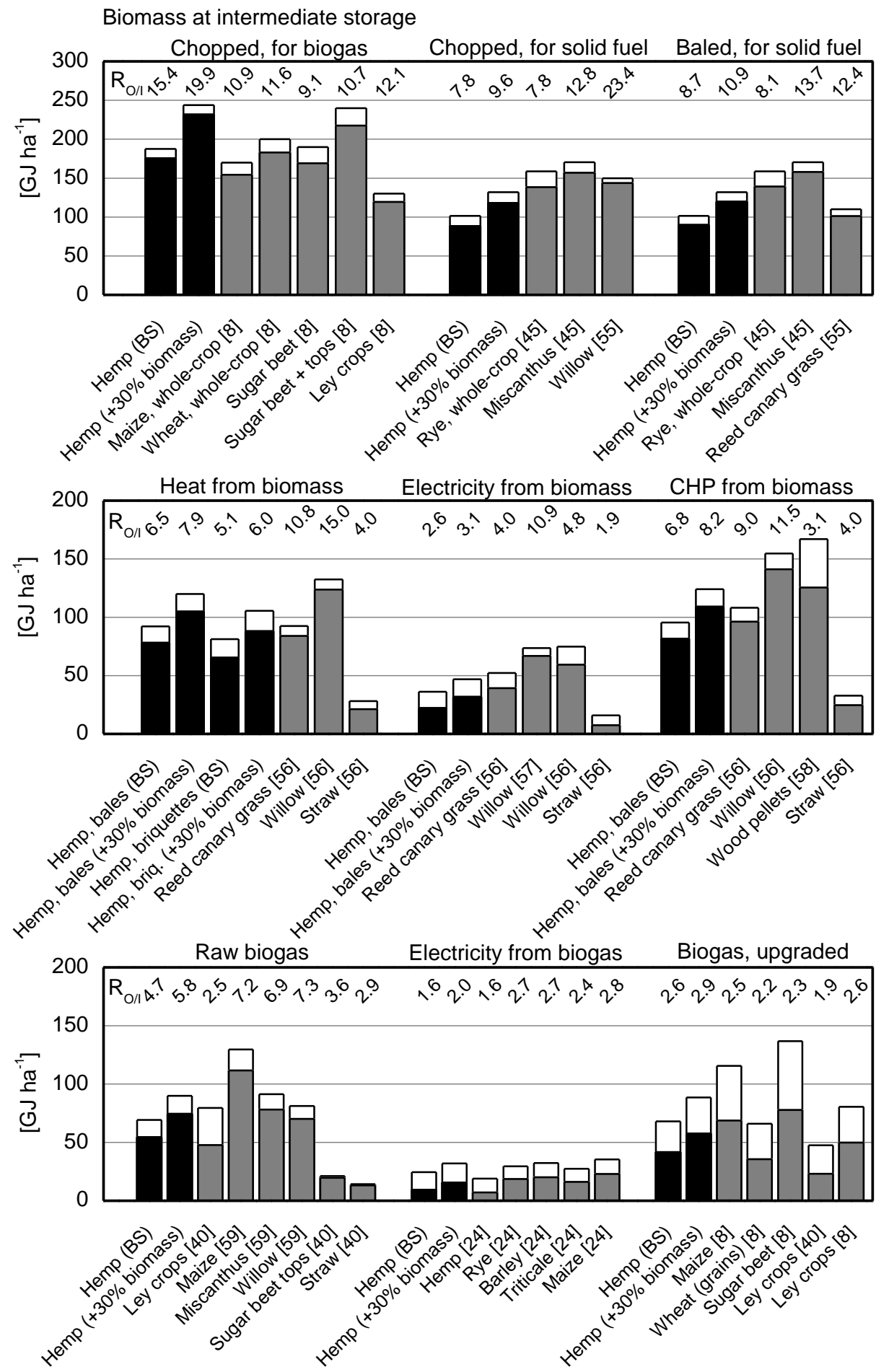